\title{
Orígenes de la Orden del Hospital en el reino de Toledo (1144-1215)
}

\author{
Enrique Rodriguez-Picavea Matilla *
}

\begin{abstract}
RESUMEN ABSTRACT
El presente trabajo analiza los origenes de la Orden del Hospital de San Juan de Jerusalén en el reino de Toledo. Para ello se estudia, en primer lugar, el protagonismo de la realeza en el proceso de implantación de los sanjuanistas en este territorio. En segundo lugar nos detenemos en el proceso de creación de las primitivas encomiendas. Un tercer aspecto tratado es el estudio de los cauces para la adquisición del patrimonio señorial de la Orden. El cuarto apartado se refiere a la distribución geográfica de las propiedades hospitalarias y su incidencia sobre la articulación fronteriza. Para finalizar con el análisis de la explotación del patrimonio sanjuanista, cuya materialización efectiva es la fiscalidad señorial.

This paper analyses the origin of the Order of the Jerusalem San Juan Hospital, in the Kingdom of Toledo. For this purpose, it is studied, firstly, the Crown's role in the process of the Order supporters settlement in this territory. Secondly, we study the creation process of the primitive Commanderies. A third aspect is the study of the ways to obtain the Order's Lordly Patrimony. The fourth point deals with the geographical distribution of the Hospitalarian properties, and their influence in the configuration of the border area. The last point is the analysis of the "San Juan" patrimony management, effectively materialized through the Lordly taxation system.
\end{abstract}

El reino de Toledo, el espacio comprendido entre el Sistema Central y Sierra Morena, fue el territorio más meridional del ámbito castellanoleo-

* Universidad Autónoma de Madrid. 
nés desde finales del siglo XI hasta las primeras décadas del siglo XIII. La organización de esta tierra fronteriza contó, desde el ecuador de la decimosegunda centuria, con el extraordinario protagonismo de las órdenes militares, entre las cuales la Orden del Hospital de San Juan de Jerusalén desempeñó un relevante papel en la zona que le llevaría a consagrarse como la orden militar internacional de mayor importancia en el reino castellanoleonés ${ }^{1}$. La intervención de la monarquía en este proceso fue absolutamente esencial, tal y como veremos a continuación. El apoyo de la realeza ${ }^{2}$ permitió a los hospitalarios la acumulación de un patrimonio muy notable en la Meseta meridional sobre el que obtener no pocas rentas y trazar las bases de una primitiva red comendataria. Todo este proceso se gestó entre la introducción de los hospitalarios en el reino de Toledo (1144) y la primera mención documental de las más meridionales fortalezas sanjuanistas en La Mancha (1215).

\section{LA REALEZA Y LA IMPLANTACIÓN DE LA ORDEN DEL HOSPITAL EN EL REINO DE TOLEDO}

\subsection{Alfonso VII y el apoyo inicial a los sanjuanistas}

En los inicios del siglo xII la Orden del Hospital de San Juan de Jerusalén se asentó en el Occidente peninsular. Así, en fecha tan tem-

\footnotetext{
1 Este trabajo fue presentado originalmente al / Simposio sobre la Historia de San Juan de Jerusalén, celebrado en Madrid durante el mes de marzo de 1990. Por razones editoriales esta contribución no aparecerá en las Actas de este Simposio, que van a ser editadas en breve. En consecuencia, nos parecía oportuno que se publicara este artículo, que ha sido convenientemente actualizado con las novedades documentales y bibliográficas que han aparecido desde entonces. Una versión diferente del trabajo que aquí presentamos apareció en el capítulo segundo de nuestro libro Las Órdenes Militares y la frontera: la contribución de las Órdenes a la delimitación de la jurisdicción territorial de Castilla en el siglo XII, Madrid, 1994. Sobre los avances historiográficos de los últimos años se pueden consultar los trabajos de C. Ayala Martínez, "Las órdenes militares hispánicas en la Edad Media. Aproximación bibliográfica", en Fr. Javier Campos (ed.), Estudios sobre las Órdenes Militares. Lux Hispaniarum. Madrid, 1999, 425-457; Ph. JosserAND, "L'historiographie des Ordres Militaires dans les royaumes de Castille et de León. Bilan et perspectives de la recherche en histoire médiévale". Atalaya. Revue française d'études médiévales hispaniques, 9 (1998), 5-44; y M.A. LADERO QUESADA, "La investigación sobre Órdenes Militares en la Edad Media hispánica durante los últimos decenios: Corona de Castilla y León", en R. Izquierdo y F. Ruiz (eds.), Las Órdenes militares en la Península lbérica, l. Edad Media. Cuenca, 2000, 9-31. Para el caso concreto de los sanjuanistas vid. C. BARQUERO GoÑI, "La Orden del Hospital en España durante la Edad Media: un estado de la cuestión", Hispania Sacra, 52 (2000), 7-20.

2 Sobre las relaciones entre los sanjuanistas y los monarcas castellanoleoneses vid. C. BARQUERO GoNI, "Los hospitalarios y la monarquía castellano-leonesa (siglos XII-XIII)", Archiyos Leoneses, 97-98 (1995), 53-119.
} 
prana como 1113, recibía de la reina doña Urraca la aldea de Paradinas, situada en la Extremadura leonesa ${ }^{3}$. En los años sucesivos, el interés de los sanjuanistas por conseguir recursos económicos para sustentar su acción en Tierra Santa verificó la consolidación de la Orden en el reino castellanoleonés de Alfonso $\mathrm{VII}^{4}$. Desde el principio de su reinado se vio clara una política de privilegios y donaciones hacia la Orden hospitalaria, que se acrecentó a partir de 1140 con la donación de la villa de Población de Campos ${ }^{5}$ y la protección de las restantes propiedades sanjuanistas en territorio castellano-leonés ${ }^{6}$.

Si bien es cierto que la mayoría de las propiedades adquiridas por la Orden se ubicaban al norte del Sistema Central ${ }^{7}$, no es menos cierto que la monarquía tampoco desaprovechó la posibilidad de implicar a los sanjuanistas en la articulación social del espacio fronterizo con los musulmanes. No debemos olvidar, por otra parte, que es precisamente en las décadas centrales del siglo XII cuando se opera la transformación de una Orden de San Juan puramente hospitalaria en otra con un componente también militar. El proceso se inicia durante el maestrazgo de Raimundo de Puy (1120-1158/1160) y termina por perfilarse en los años siguientes ${ }^{8}$.

3 Es la actual localidad salmantina de Paradinas de San Juan. Publ. Domingo AGuiRre, El Gran Priorato de San Juan de Jerusalén en Consuegra, en 1769, Toledo, 1973, pp. 41-42; Carlos de Ayala Martinez (comp.), Libro de Privilegios de la Orden de San Juan de Jerusalén en Castilla y León (siglos Xil-xv), Madrid, 1995, $n .{ }^{\circ} 1$ (en lo sucesivo se aludirá a él con la denominación de Libro de Privilegios, seguido del número correspondiente que lleva cada documento en la publicación).

${ }_{4}$ El interés económico de la Orden en sus territorios peninsulares ya fue puesto de relieve por Santos Garcia Larragueta, "La Orden de San Juan en la crisis del Imperio hispánico del siglo xil», Hispania, 12 (1952), 483-524. Por otra parte, para todo lo concerniente a los orígenes de la Orden en los reinos occidentales vid. el documentado trabajo de Carlos de Ayala MARTínez, "Orígenes de la Orden del Hospital en Castilla y León (1113-1157)", Hispania Sacra, 43 (1991), 775-798.

5 Publ. J.V. Matellanes Merchán y E. Rodriguez-Picavea Matilla, "Las Órdenes Militares en las etapas castellanas del Camino de Santiago", en H. Santiago Otero (ed.). El Camino de Santiago, la hospitalidad monástica y las peregrinaciones, Salamanca, 1992, pp. 361-363; Libro de Privilegios, n. 44.

6 Publ. P. Rodriguez Campomanes, Disertaciones históricas del Orden y Caballeria de los Templarios, Madrid, 1747 (edición facsímil, Barcelona, 1975), pp. 246-247; Libro de Privilegios, ก. ${ }^{\circ} 43$.

Sobre las donaciones del reinado de Alfonso VII y su distribución geográfica remitimos al mencionado trabajo de C. de AYALA, "Origenes de la Orden del Hospital», pp. 781-790.

8 A.J. FoREY, "The Militarisation of the Hospital of St. John", Studia Monastica, 26 (1984), 75 89. El debate historiográfico sobre esta cuestión y la oportunidad de la utilización del término militarización para aludir a este proceso en L. Garcia-guijarro Ramos, Papado, Cruzadas y órdenes militares, siglos XI-XII, Madrid, 1995, pp. 142-148; Id., "La militarización de la Orden del Hospital: líneas para un debate", en I. Fernandes (ed.), Ordens Militares: guerra, religião, poder e cultura. Actas do III Encontro sobre Ordens Militares, Lisboa-Palmela, 1999, II, 293-302; y Carlos de AvalA MARTíneZ, "Orígenes e implantación de la Orden de San Juan de Jerusalén en la Península lbérica (siglo x\|)", en R. Izquierdo, F. Ruiz y J. Molero, eds., La Orden Militar de San Juan en la Península 
La primera noticia de la presencia hospitalaria en el reino de Toledo procede de la década de 1140. En concreto de 1144, cuando el propio Alfonso VII cedió a la Orden el estratégico castillo de OImos ${ }^{9}$, que controlaba el tránsito en la vía de penetración natural del Guadarrama ${ }^{10}$. Es importante subrayar que la introducción de la los hospitalarios en el reino de Toledo se realiza de la mano de la realeza y que se materializa en la cesión de una fortaleza en un momento en el que la Orden comienza a ser vista como una institución asociada con una cierta actividad militar. La plaza concedida cuenta además con jurisdicción propia sobre el territorio circundante. En consecuencia el hecho no parece meramente casual, sino que responde a un plan monárquico de implicación de los hospitalarios en la frontera meridional del reino castellanoleonés, que se encuentra en plena contraofensiva frente a los almorávides.

Al mediar el siglo, la Orden probablemente consiguió infiltrarse en posiciones más meridionales, situadas en la frontera abierta frente a los musulmanes. Según Aguirre, en 1150 el infante don Sancho, actuando ya como monarca, entregó a la Orden la aldea de Arenas de San Juan ${ }^{11}$. La noticia no hemos podido contrastarla con otras fuentes, pero de ser cierta significaría el inicio de la fructífera presencia de los hospitalarios en La Mancha. Finalmente, es probable que, según la versión del fuero de Peñalver, el emperador castellano-leonés interviniera en la cesión de esta aldea alcarreña a la Orden, donada a los freires por el concejo de Guadalajara ${ }^{12}$.

Ibérica durante la Edad Media. Actas del Congreso Internacional celebrado en Alcázar de San Juan los días 23, 24 y 25 de octubre de 2000, Alcázar de San Juan, 2002, 23-41, pp. 38-41. Los datos que poseemos para el ámbito castellanoleonés los ha recogido Carlos BARQUERO GoÑ, "EI carácter militar de la Orden de San Juan en Castilla y León (siglos XII-xV)", Revista de Historia Militar, 73 (1992), 53-80.

9 Libro de Privilegios, n. 51.

10 G. MARtinez Díz, "Estructura administrativa local en el naciente reino de Toledo", Actas del II Congreso Internacional de Estudios Mozárabes. Estudios sobre Alfonso VI y la Reconquista de Toledo, II, Toledo, 1988, pp. 92-95; J. GonzÁlez, Repoblación de Castilla la Nueva, 2 vols., Madrid, 1975-1976, I, p. 195. La identificación de Olmos con el hisn islámico de Walmus en L. TORRES BALBÁs, "Ciudades yermas de la España musulmana", Boletín de la Real Academia de la Historia, 141 (1957), p. 52; y Sergio MARTinEz LILLO, «Primeros materiales arqueológicos del castillo de Olmos. El Viso de San Juan (Toledo)", I Congreso de Historia de Castilla-La Mancha, Toledo, 1988, V, 273-278; y "El poblado fortificado de Olmos", Madrid del siglo Ix al xl, Madrid, 1990, p. 134.

11 Biblioteca del Palacio Real de Madrid, Ms. 1531, fol. 121. Por su parte Pedro GuerRero Ventas (El Gran Priorato de San Juan de Jerusalén en el Campo de La Mancha, Toledo, 1969, p. 39) considera que la donación se hizo a expensas de los términos del castillo de Consuegra, ya que efectivamente Arenas se situaba dentro del limite meridional concedido a la fortaleza en 1151.

12 Libro de Privilegios, $n .^{\circ} 76$ y 77 . La fecha concreta de la donación la desconocemos, pero debió producirse durante los últimos años del reinado de Alfonso VII por la aparición de sus hijos Sancho y Fernando como confirmantes del documento foral. 
Durante los últimos años del reinado de Alfonso VII no tenemos noticias fidedignas sobre otras donaciones en territorio fronterizo. Las observaciones realizadas por Domingo Aguirre y Pedro Guerrero ${ }^{13}$ en relación a que el monarca castellano-leonés donó a la Orden del Hospital las aldeas de Cedillo ${ }^{14}$, Humanes ${ }^{15}$, Alcázar ${ }^{16}$ y Santa María ${ }^{17}$, carecen de fundamento, ya que en realidad todas ellas fueron entregadas a particulares. Por el contrario, sí conservamos datos sobre la adquisición de patrimonio hospitalario en la Meseta septentrional por el doble cauce de las donaciones reales y particulares ${ }^{18}$. La continuidad de las excelentes relaciones entre la Orden y la monarquia se confirmó con la concesión de un privilegio, otorgado por el emperador en 1156, a través del cual este último tomaba bajo su protección y concedía inmunidad a todas las propiedades de la Orden, al tiempo que eximía a sus hombres de cualquier servidumbre ${ }^{19}$. En esa misma línea, con el objetivo de que la Orden alcanzara mayor eficacia, aunque desde una perspectiva bien diferente, el legado pontificio para España, cardenal Jacinto, exhortó a los arzobispos, obispos, abades, templarios y hospitalarios a luchar conjuntamente contra los musulmanes ${ }^{20}$. Guerrero.

13 Vid. D. Aguirre, El Gran Priorato, pp. 159-160. Las notas a pie de página son de Pedro

${ }_{14}$ Se trata en realidad de la donación realizada por Alfonso VII, el 4 de febrero de 1129, a favor de Menendo Bofino, al que le otorgaba la heredad que fue de Cidelo en Talavera (Libro de Privilegios, $n .{ }^{\circ} 25$ ).

15 Desde Segovia, el 21 de febrero de 1141, el emperador castellanoleonés donó a Pedro Brimón la villa de Humanes (ibid., n. ${ }^{\circ} 46$ ).

16 El 22 de marzo de 1149 Alfonso VII donó a Juan Muñoz, Fernando González y Pedro Rodriguez la villa de Alcázar (ibid., n. ${ }^{\circ} 56$ ).

17 El 18 de febrero de 1156 en Toledo, Alfonso VIl dio a Pelayo Cabeza, Pedro Cabeza, Martin Oduariche y Miguel Ibáñez Coronel tres partes de la aldea de Santa Maria, situada en el término de Toledo. Vid. Archivo Histórico Nacional, Órdenes Militares (en adelante AHN, OO.MM.), carp. 568, n. ${ }^{\circ}$ 2. La reseña también en AHN, OO.MM., Índice 121, fol. 31; Índice 160, fol. 96; J. GonzÁlez, Repoblación, I, p. 210. Por su parte P. Guerrero Ventas (El Gran Priorato, p. 40) considera que la donación fue hecha al Hospital a través de los cuatro beneficiarios de la misma, que eran "donados" de la Orden. Sin embargo, nada de esto se desprende del texto del documento, al que parece que Guerrero no tuvo acceso. Por lo tanto, cabe concluir que se trata de una donación a particulares que, andando el tiempo, y no sabemos en qué momento, fue a parar, por uno $u$ otro cauce, a poder de la Orden.

18 C. de AyALA, “Orígenes de la Orden del Hospital», pp. 787-796.

19 Publ. P. Rodriguez Campomanes, Disertaciones históricas, pp. 242-244; J. Delaville LE Roulx, Cartulaire Générale de l'Ordre des Hospitaliers de S. Jean de Jérusalem (1100-1310), 4 vols., Paris, 1894-1906, !, pp. 186-187; Libro de Privilegios, n. ${ }^{\circ}$ 11. Existen otros dos privilegios de carácter general entregados por el propio Alfonso VII a la Orden del Hospital, fechados en 1152 y 1156, pero sus numerosas anomalías e interpolaciones permiten dudar acerca de su autenticidad. Cir. C. de AyALA, “Orígenes de la Orden del Hospital», p. 789, nota 56.

20 Publ. Demetrio MANSILLA, La documentación pontificia hasta Inocencio III (925-1216), Roma, 1955, pp. 116-117. El documento carece de fecha, Mansilla propone la de 1155 basándose en la legación del cardenal Jacinto en España. 


\subsection{Debilidad de la monarquía castellana e inicios del apoyo nobiliario en el reino de Toledo}

Asentada la Orden en Castilla, durante la minoría de edad de Alfonso VIII (1158-1170) se infiltró en avanzadas posiciones fronterizas debido a la confianza que depositaron en ella los magnates que controlaban los resortes del poder real. De este modo, en enero de 1162, Alfonso VIII, con el consejo y el favor de los barones de su reino y de su regente el conde Manrique de Lara, confirmaba todas las donaciones efectuadas a la Orden del Hospital y le concedía además las villas manchegas de Criptana, Ajos, Quero y Tirez ${ }^{21}$. Sin embargo, ese mismo mes de enero el prior de la Orden en Hispania, frey Villano, donaba a Miguel Asarafí la mitad de cada una de las cuatro villas, ut tu turrim illic edifices et utraris fieri nobis et tibi commoda cultam ${ }^{22}$, demostrando así la imposibilidad de hacerse cargo en solitario de la colonización de estos lugares y la necesidad de construir un elemento fortificado que actuara como núcleo de articulación espacial de estas tierras fronterizas ${ }^{23}$.

No obstante, los que coyunturalmente dominaban el poder real continuaron teniendo en cuenta a la Orden para la defensa de la frontera andalusí, como demuestra la donación del castillo de Uclés - con toda su villa-, que Fernando II de León y Alfonso VIII de Castilla verificaron a favor de los sanjuanistas en septiembre de $1163^{24}$. La entrega de Uclés, que estratégicamente situada controlaba a los musulmanes de Cuenca y amplios territorios de La Mancha semidespoblada, significaba la gran oportunidad para la Orden de implicarse en la organización social del espacio fronterizo y desarrollar un amplio territorio bajo condiciones señoriales ${ }^{25}$.

\footnotetext{
21 AHN, OO.MM., carp. 4†8, n. ${ }^{\circ}$ 21. Publ. J. González, Alfonso VIII, II, pp. 97-99.

22 AHN, OO.MM., carp. 455, n. ${ }^{\circ}$; ibid., sign. $1349 \mathrm{c}$, fol. 42; Real Academia de la Historia (en adelante RAH), col. Salazar, sign. 9-612, fol. 295. Publ. C. BARouero Goñ, Los hospitalarios en Castilla y León (siglos x/l y xill), Madrid, 1995 (edición en microfichas), apéndice documental,

${ }^{23}$ J. GONZÁLEZ (Repoblación, I, p. 280 y "La repoblación de La Mancha», en VII Centenario del infante don Fernando de la Cerda, Ciudad Real, 1976, p. 6) señala que la donación se hizo para que Miguel Asarafí colaborase en la repoblación y construyese un castillo.

${ }_{24}$ El documento original, según J. Gonzalez (El reino de Castilla en la época de Alfonso VIII, 3 vols., Madrid, 1960, III, p. 788), estuvo en la Colección Bauer de la Real Academia de la Historia hasta 1936, pero actualmente se encuentra en paradero desconocido. Se conservan copias del mismo publicadas en C. de Ayal.A MARTinez y otros, "Algunos documentos sobre Ordenes Militares y fortalezas", Castellum, 1 (1992), pp. 90-91; y Libro de Privilegios, n. 91.

25 Las magníficas posibilidades para la constitución de un señorío las demostraría poco después la Orden de Santiago, al convertir a Uclés en sede de una importante encomienda y priorato. Vid. Milagros Rivera Garretas, La encomienda, el priorato y la villa de Uclés en la Edad Media (1174-1310). Formación de un señorío de la Orden de Santiago, Madrid-Barcelona, 1985.
} doc. 73. 
Por otra parte, a finales de la década de 1160 la nobleza castellana empezó a favorecer a la Orden con donaciones en la frontera ${ }^{26}$. En marzo de 1168 la condesa doña Ermesinda cedió a los sanjuanistas unos molinos en el río Tajuña ${ }^{27}$. A finales de junio de ese mismo año, el conde don Gonzalo ${ }^{28}$ y su mujer doña Milia realizaron una donación más importante, consistente en la aldea de Villamiel y toda su heredad en Toledo y su término, compuesta por la Almuzavara - situada próxima a la almunia regia-, además de casas, molinos, tiendas y hornos. En la donación se incluía también tota hereditas que fuit de infanta donna Sanctia, cedida por Sancho III y confirmada por Alfonso VIII. La operación contaba ahora con la aprobación de este último monarca ${ }^{29}$.

\subsection{El priorato de Pedro Arias y el crecimiento patrimonial en el reino de Toledo}

Entre 1170 y la segunda mitad de la década de 1180 se extiende el período de mayor prestigio y crecimiento fronterizo de la Orden del Hospital, que coincide cronológicamente con el priorato de Pedro Arias ${ }^{30}$. Este prior sanjuanista fue un personaje destacado en las cortes de Fernando II y Alfonso VIII, por lo que intervino en varias misiones diplomáticas, como la embajada castellana de 1177 en Londres o la mediación, junto con el maestre santiaguista Pedro Fernández, entre castellanos y leoneses en los tratados de Medina de Rioseco (1181) y Fresno-Lavandera (1183), reteniendo varios castillos en garantía de fidelidad ${ }^{31}$.

26 Las relaciones entre la Orden y la nobleza han sido analizadas para el ámbito castellanoleonés por C. BARQUERo GoÑI, "Los hospitalarios y la nobleza castellano-leonesa (siglos XII-XIII)", Historia. Instituciones. Documentos, 21 (1994), 13-40.

27 Libro de Privilegios, n. 100.

28 Probablemente se trata del conde Gonzalo Rodríguez, perteneciente a la casa de Manzanedo. Sobre la figura de este magnate vid. J. GonzALEZ, Alfonso VIII, I, p. 337; y Simon BARTON, The Aristocracy in Tweifth-Century León and Castile, Cambridge, 1997, pp. 260-261.

29 Libro de Privilegios, n. 101.

30 La primera mención documental a Pedro Arias, Pedro de Areis o Pedro de las Eras, como prior de la Orden del Hospital data de marzo de 1170 (Libro de Privilegios, n. ${ }^{\circ} 105$ ). En la donación realizada en julio 1169 por Fernando II a Pedro Arias de la aldea de Lapamala, - a pesar de lo que se pensaba hasta ahora (S. Garcia LARRAGueta, "La Orden de San Juan en la crisis", $p$. 507 ) - no figuraba todavía como prior hospitalario (Libro de Privilegios, $n{ }^{\circ}$ 104). En consecuencia, su acceso al cargo debe situarse en los nueve meses que transcurren entre las fechas que acabamos de mencionar. La última mención documental al prior Pedro Arias es de junio de 1186 (C. BARQuero Goñi, Los hospitalarios en Castilla y León [siglos xil y xill], doc. 11). Dos años después aparece ya Martín Pérez como nuevo prior sanjuanista (Libro de Privilegios, $n .{ }^{\circ} 161$ ).

31 La embajada a la corte inglesa y los tratados fronterizos en J. GonzÁLEZ, Alfonso VIII, II, pp. 456-461, 614-623 y 701-708. Sobre el prestigio alcanzado por Pedro Arias en la diplomacia de la época vid. S. García Larragueta, "La Orden de San Juan en la crisis", pp. 499-500. 
El nuevo prior contaba con el apoyo renovado del monarca castellano. En 1170 Alfonso VIII acogió bajo su protección las casas, ganados y cabañas de la Orden del Hospital, y ordenó multas contra quienes deshonrasen a sus freires ${ }^{32}$. Ese mismo año el propio monarca intervino en el enriquecimiento del patrimonio señorial de la Orden donando a los sanjuanistas unas heredades en Torrejón ${ }^{33}$. Tampoco descuidó el prior Pedro Arias sus posesiones fronterizas en este período. El propio prior hospitalario tomaba la iniciativa en la colonización del Alto Tajo, al aprobar el fuero, inspirado en el de Huete, otorgado por el prior Juan a la villa de Alhóndiga ${ }^{34}$. Sin embargo, la acción de los particulares y la monarquía en beneficio de los hospitalarios se centró particularmente en el alfoz toledano. En marzo de 1170 los freires conseguían la cesión definitiva de Villamiel por parte de la condesa doña Elvira ${ }^{35}$. Esto atrajo nuevas donaciones a favor de los sanjuanistas en la aldea. Cuatro años después, Pedro y Sancho Ibáñez cedieron al Hospital toda su heredad en Villamiel, aunque retuvieron el usufructo vitalicio a cambio de una renta anual de una fanega de trigo ${ }^{36}$. En febrero de 1176 el propio Alfonso VIII confirmaba a los hospitalarios la posesión de la aldea de Villamiel ${ }^{37}$. En otra aldea

32 Publ., entre otros, J. González, Alfonso VIII, II, pp. 238-39.

33 D. Aguirre, El Gran Priorato, p. 163. A pesar de la abundancia del topónimo «Torrejón», es muy probable que se trate de un lugar situado en la Meseta meridional, ya que casi la totalidad de los topónimos de ese nombre localizados en el territorio de la monarquía castellana del siglo Xı se encuentran en las actuales provincias de Guadalajara, Cuenca y Madrid. Vid. Pascual MADOz, Diccionario geográfico-estadístico-histórico de España y sus posesiones de Ultramar, 16 vols., Madrid, 1845-1850, voz Torrejón.

34 Publ. Juan Catalina Garcia LóPez, "Carta-puebla de Alhóndiga", Boletín de la Real Academia de la Historia, 35 (1899), pp. 472-476; Eduardo de HINojosA, Documentos para la historia de las Instituciones de León y Castilla (sigios $x$-xill), Madrid, 1919, pp. 74-77; Antonio PAREJA SerRadA, Diplomática Arriacense, Guadalajara, 1921, pp. 131-138 (traducción en las mismas páginas). En adelante, las referencias al fuero de Alhóndiga se harán siguiendo la edición de Hinojosa, que nos parece la más fidedigna de las tres. No obstante, cabe reseñar que no incluye en su publicación un fragmento final que si figura en la edición de García López, aunque parece un añadido posterior no relacionado con lo otorgado por la Orden en 1170 - al menos figuran disposiciones probablemente emanadas del gobierno concejil, ya que regulan el pago de los tributos municipales. A mediados del siglo XIII, el comendador hospitalario en Hispania, Raimboldo, junto con el Capitulo de la Orden reunido en Fresno el Viejo, confirmó a los pobladores de Alhóndiga el fuero que les concedió el prior Juan cuando pobló la aldea. Sin embargo no parece posible fechar esta confirmación en 1170 (Esta datación aparece en C. BARQUERO GoÑı, Los hospitalarios en Castilla y León [siglos $x \|$ y $x I I 1$ ], doc. 93. No obstante, en el texto el propio autor expresa sus dudas sobre la cuestión). La figura del gran comendador hispánico no aparece en la documentación hasta finales del siglo xII (GARCIA LARRAGUETA, "La Orden de San Juan en la crisis", pp. 493494 y 497-498), mientras que Raimboldo puede ser identificado con Riumbaldo o Reonibalt, que se documenta como comendador mayor de España o gran comendador de los Cinco Reinos de España en documentos de la década de 1240 (Libro de Privilegios, n. 287 y 288).

35 Libro de Privilegios, $\mathrm{n} .^{\circ} 105$

36 lbid., n. ${ }^{\circ} 116$.

37 Ibid., n. ${ }^{\circ} 124$. 
toledana, Mazarabuzaque ${ }^{38}$, los sanjuanistas consiguieron del rey siete aranzadas de viña (1186) y compraron una heredad a Maria Pascual $(1187)^{39}$. El patrimonio sanjuanista se extendió también a Camarena, situada como las anteriores en el término de Toledo, donde en 1185 Martín Pérez y su mujer donaron una heredad, con casas y corral ${ }^{40}$.

En 1183, y en la propia ciudad de Toledo, Domingo Pérez donó la iglesia de Santa Cruz, antigua mezquita musulmana ${ }^{41}$. Un año después, se producia un acuerdo entre doña Misol y la Orden acerca de una casa en Toledo y una viña en Aceca ${ }^{42}$. Más al norte, en enero de 1176 Pelayo Pérez de Frómista entregó a la Orden del Hospital la villa de Humanes de Madrid, además de unas casas en la propia ciudad del Tajo ${ }^{43}$. Por su parte, en 1182 el monarca castellano donó a los sanjuanistas cuatro yugadas de heredad en la ribera del Tajuña ${ }^{44}$.

Al sur del Tajo, entre la cuenca alta de este río y su afluente el Guadiela, Alfonso VIII donó en 1184 a la Orden del Hospital salinas, huertos y otros bienes en Beteta y el término de Cuenca ${ }^{45}$. En el extremo opuesto de la frontera meridional castellana, Pedro Cabañero y su mujer cedieron en 1182 unas tierras en la aldea de Borgel, situada en el extenso y solitario alfoz de Talavera ${ }^{46}$.

Mientras tanto, años antes, en 1174, Alfonso VIII había decidido donar Uclés a la Orden de Santiago ${ }^{47}$, en compensación el monarca castellano entregó a la Orden del Hospital la villa de Espinosa, situada muy lejos de la frontera andalusí, en el alfoz de Abia ${ }^{48}$. Tres son las posibles causas que pudieron motivar esta decisión: la acción de los hospitalarios en los extremos del reino, que pudo defraudar las expectativas de la Corona, el rechazo a la política de Fernando II en Castilla y la plena implicación de la Orden de Santiago en la frontera castellano-andalusí.

38 Su localización dentro del alfoz toledano en G. MARTinez Diez, «Estructura administrativa», p. 129; y J. GonzÁLEZ, Repobiación, II, mapa situado entre las páginas 176 y 177.

39 Libro de Privilegios, $n .^{\circ} 157$ y 160.

40 lbid., n. 156. Camarena pertenecía a la jurisdicción del concejo toledano. Vid. G. MARTínEz Diez, “Estructura administrativa”, p. 123 y J. GonzÁLEZ, Repoblación, 1, p. 204.

41 Libro de Privilegios, n. 145.

42 Ibid., n. 152.

43 Ibid., n. 123

44 lbid., n. ${ }^{\circ} 141$

45 lbid., n. ${ }^{\circ} 154$

46 Ibid. n. ${ }^{\circ} 142$

47 Publ., entre otros, J.L. Martin Rodriguez, Origenes de la Orden Militar de Santiago (1170 1195), Barcelona, 1974, pp. 240-241. Reg. M.Rivera Garretas, La encomienda, p. 231.

48 Publ. J. Gonzalez, Alfonso VIII, II, pp. 321-322. 
La primera no puede ser corroborada documentalmente, pero tampoco cabe descartarla plenamente. Resulta evidente que si los sanjuanistas hubieran satisfecho totalmente las expectativas de la Corona probablemente la sustitución no se habría producido. La entrega de una villa septentrional como compensación por la pérdida de Uclés incide en la misma idea. Naturalmente, la actuación del Hospital no podía ser comparable al abandono templario de la fortaleza de Calatrava, pero la política general de la Orden estaba demasiado mediatizada por intereses extrapeninsulares. Por otra parte, tampoco debe descartarse el rechazo a la política del monarca leonés en la época durante la cual ejerció su tutela sobre el monarca castellano, opinión que recoge el Tumbo Menor de Castilla, redactado por los santiaguistas de Uclés ${ }^{49}$. Con todo, la tercera de las causas parece la más evidente por el desarrollo de los acontecimientos posteriores. Se trataba de convertir a la Orden de Santiago, nacida en el reino de León, en una institución también castellana. El proceso de castellanización de los santiaguistas tendría como referencia básica la fortaleza de Uclés, al mismo tiempo que se implicaba a los freires en el sector suroriental de la frontera en el momento en que la expansión castellana apuntaba a la conquista de Cuenca. Para llevar a cabo este proyecto se prefiere a una Orden hispánica, notablemente menos mediatizada por intereses y poderes extrapeninsulares que la Orden del Hospital. En opinión de Julio González influyeron también las presiones del legado pontificio cardenal Jacinto, la pérdida de la sede santiaguista de Cáceres y la mayor actividad militar de la Orden hispánica en la frontera ${ }^{50}$. El éxito del proyecto de castellanización de los santiaguistas tendría su reflejo en la documentación posterior que comenzó a conocer a la institución con la denominación de Orden de Uclés.

Desde la pérdida de Uclés, junto a la acumulación de propiedades con objetivos económicos, el objetivo de los hospitalarios y de su prior Pedro Arias debió ser conseguir una fortaleza estratégica en la frontera, base para el futuro desarrollo de un amplio señorío. La idea no era ajena tampoco a los intereses de la Corona, particularmente cuando el componente militar de los sanjuanistas resultaba difícil de cuestionar ${ }^{5 t}$. Así, en agosto de 1183, Alfonso VIII donaba a la Orden del Hospital y a su prior Pedro Arias el castillo de Consuegra, in fronteria maurorum prope Toletum

J.L. Martin, Origenes, p. 241; y M. Rivefa Garretas, La encomienda, pp. 36 y 232.

J. Gonzalez, Alfonso VIII, I, p. 504.

La mayor implicación de la Orden en la defensa fronteriza no debe desligarse de la primera mención expresa a los fratres armorum recogida en los estatutos hospitalarios de 1182 . Publ. J. DELAVILLE, Cartulaire, $1, \mathrm{n} .{ }^{\circ} 627$. 
situm $^{52}$, con lo que implicaba definitivamente a los sanjuanistas en la defensa del reino de Toledo ${ }^{53}$. Por otra parte, la donación, al tiempo que suponía la continuación de la política real con respecto a la utilización de las Órdenes militares como instrumentos de la monarquía castellana, introducía un elemento neutralizador entre los señoríos de las Órdenes de Calatrava y Santiago ${ }^{54}$. La implicación de los hospitalarios en la defensa de la frontera castellano-andalusí contaba con el decidido apoyo de la Iglesia de Roma y del papa Lucio III que, a petición de la Orden, se apresuró a confirmar la donación de Consuegra en el mismo mes de agosto de $1183^{55}$.

El incremento del patrimonio señorial hospitalario seguía contando también con el apoyo de la alta nobleza, que en algunos casos entregó todos sus bienes y heredades en varios lugares del reino. En contrapartida la Orden era un buen cauce para la canalización de las aspiraciones religiosas de los magnates. Así, en septiembre de 1173, el conde Pedro de Asturias se entregó a la Orden del Hospital con todas sus heredades en Galicia, Asturias, León, Castilla y Nájera ${ }^{56}$. Tres años después la reina doña Urraca, quod sum professa in ipso Ordine, donaba a los hospitalarios Castroverde de Campos, Mansilla, Salas, San Andrés y Cedeira, con reserva parcial de usufructo ${ }^{57}$. En 1178 la condesa doña Elvira se entregaba también a la Orden, comprometiéndose a tomar el hábito sanjuanista o donar al Hospital cuantas heredades en Galicia, Asturias, León y Castilla había recibido en arras de su marido el conde Pedro Alfonso ${ }^{58}$. Un lustro más tarde, Gutierre

52 La donación de Consuegra está fechada el 6 de agosto de 1183 en Palencia. Publ. I. Clemente de Arostegui, Concordia Pastoralis super jure diocesano, Compluti, 1734, pp. 184-185; P. Guerrero Ventas, El Gran Priorato, pp. 332-333; Libro de Privilegios, n. 144 . La copia romanceada en D. AguirRE, El Gran Priorato, pp. 52-53.

53 Jesús Molero ha cuestionado esta implicación basándose en la pérdida de valor de la fortaleza consaburense y el papel más relevante jugado por las órdenes hispánicas. Vid. J. MOLERo García, «Participación de la Orden del Hospital en el avance de la frontera castellana (11441224)", en R. Izquierdo y F. Ruiz (eds.), Alarcos 1195. Actas del Congreso Internacional Conmemorativo del VIII Centenario de la Batalla de Alarcos, Cuenca, 1996, 331-351, pp. 340346. Resulta evidente la mayor relevancia alcanzada en las actividades militares por calatravos y santiaguistas, pero al mismo tiempo no es posible negar que a partir de la donación de Consuegra los sanjuanistas se implican en la defensa del reino de Toledo, aunque su faceta se viera reducida "casi en exclusiva a la defensa de sus posesiones" (p. 346).

54 El posterior desarrollo de los términos señoriales de las fortalezas de Calatrava, Consuegra y Uclés confirma este hecho. En la misma línea del carácter neutralizador vid. P. GUERRERO VENTAS, El Gran Priorato, pp. 57-58.

55 Publ. 1. Clemente de Arostegui, Concordia Pastoralis, p. 185; P. Guerrero Ventas, El Gran Priorato, p. 337. La versión romanceada en D. AguirRe, El Gran Priorato, pp. 53-54. A través de este documento se constata que la donación de Consuegra a los hospitalarios contó con la aprobación de su anterior señor Rodrigo Rodríguez.

56 Libro de Privilegios, n. 111.

57 lbid., n. ${ }^{\circ} 127$

58 lbid., n. 130. 
Rodríguez y su mujer la condesa doña Elvira se comprometieron a entrar en la Orden en caso de decidirse por la vida religiosa ${ }^{59}$.

\subsection{Consolidación y reorganización del señorío sanjuanista}

Después de la fructífera etapa del priorato de Pedro Arias, la Orden del Hospital experimenta una fuerte ralentización en el ritmo de su crecimiento fronterizo. Así, entre finales de 1188 y finales de 1200 los freires sanjuanistas no reciben ninguna donación -ni de procedencia real ni particular - en el reino de Toledo. Anteriormente, sólo conocemos la donación de la heredad que tenía Pedro Domínguez en Cadalso, verificada por Alfonso VIII a favor de la Orden en septiembre de $1188^{60}$. En consecuencia, los hospitalarios se dedicaron básicamente en esta etapa a la consolidación y reorganización del patrimonio recibido con anterioridad.

No obstante, las relaciones con la monarquía castellana continuaban siendo satisfactorias. En noviembre de 1190 el rey concedía franquicia a unas tiendas que tenía la Orden del Hospital en Toledo ${ }^{61}$. Al mismo tiempo, tampoco descuidaba el monarca castellano la solidez del patrimonio sanjuanista en posiciones de frontera abierta. Así, en 1194 confirmó a la Orden la donación de Arenas de San Juan, que había realizado su padre Sancho III ${ }^{62}$. Incluso mantenía buenas relaciones con el maestre de Amposta don Armengol, al que donó la villa de Novo, situada cerca de Huesca ${ }^{63}$.

La ausencia de donaciones fronterizas, una de cuyas causas pudo ser la asfixiante presión almohade de la década de 1190, llevó a la Orden a adquirir nuevas propiedades por medio de compra-ventas. En junio de 1192 el comendador sanjuanista de Talavera Pedro de Lamas compró a doña Águeda la aldea de Pedro Pérez el Tuerto, situada en el término de Talavera, junto al Alberche, a cambio de 33 maravedís ${ }^{64}$. Al año siguiente,

59 Publ. S. Garcia LarRagueta, “La Orden de San Juan en la crisis», pp. 522-524.

60 Libro de Privilegios, $n{ }^{\circ} 164$.

61 lbid., n. ${ }^{\circ} 173$.

62 Biblioteca del Palacio Real de Madrid, Ms. 1531, fol. 121-122; D. AguiRre, El Gran Priorato, pp. 138-139, nata 32. Poco después se despobló, probablemente por la presión almohade, quedando tan sólo la iglesia (sobre ella vid. E. SÁINZ MAGAÑA, "Un monumento románico en la provincia de Ciudad Real: la iglesia de Arenas de San Juan", I Congreso de Historia de Castilla-La Mancha, Toledo, 1988, V, 273-278). En marzo de 1236 el comendador de Consuegra Fernando Rodríguez repobló el lugar con terreno para 200 vecinos.

63 Publ. J. GonzÁlez, Alfonso VIII, II, pp. 963-964.

64 La vendedora entrega a la Orden los 33 maravedis recibidos por amorem Dei et animas parentum meorum et omnium fidelium deffunctorum, ad Sanctum lohanem de Hospitale, ut habeamus partem in orationem fratrum Hospitalis. Publ. Libro de Privilegios, $n .176$. 
Pedro Cañadilla vendió a la Orden del Hospital unas heredades en Cañadilla, situada también en el alfoz talaverano, por quince maravedís ${ }^{65}$. En 1198 los sanjuanistas incrementaron sus posesiones territoriales en la villa de Humanes, al comprar una heredad a doña Columba por 40 maravedís $^{66}$. Cinco años antes, el conde don Fernando les había devuelto la citada villa madrileña, que había recibido vitaliciamente durante el priorato de Pedro Arias, a cambio de 714 maravedis ${ }^{67}$.

En esos años finales del siglo xII se hacía sentir con fuerza la acción almohade sobre la frontera. Por eso el papa Celestino III, en noviembre de 1193, exhortó a los hospitalarios de España y Provenza a romper la tregua con los musulmanes, sin mezclarse en las querellas internas de los reyes cristianos, para lo cual les concedía algunos privilegios con objeto de proseguir la lucha ${ }^{68}$. Sin embargo, el desastre para los castellanos llegó tras la derrota de Alarcos (1195), con la pérdida de los territorios situados entre los Montes de Toledo y Sierra Morena, fundamentalmente el Campo de Calatrava. La fortaleza de Consuegra quedaba ahora en primera línea de la vanguardia fronteriza, con los almohades situados a escasa distancia, en la torre de Guadalerza. En opinión de Julio González el papel del castillo sanjuanista en la frontera fue marginal y las treguas firmadas con los musulmanes en 1197 serían salvadoras para la supervivencia de Consuegra ${ }^{69}$.

Durante los años del tránsito del siglo XII al XIII Consuegra fue objeto de no pocas atenciones por parte de la realeza, lo que cuestiona que, al menos desde la perspectiva de la monarquía castellana, su papel fuera marginal en la estructura defensiva toledana. La importancia de la fortaleza sanjuanista ${ }^{70}$ en la nueva configuración fronteriza preocupaba a Alfonso

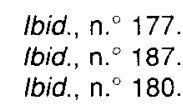

68 Pubi. S. Garcia Larragueta, El Gran Priorado de Navarra de la Orden de San Juan de Jerusalén. Siglos XII-XII, 2 vols., Pamplona, 1957. II, pp. 554-555. Sobre el apoyo de los pontífices romanos a la Orden vid. la documentación contenida en Juan CARRAsco PEREZ, "Bulas sanjuanistas del Gran Priorado de Navarra (1113-1312)", Anuario de Estudios Medievales, 11 (1981), 516-548.

69 J. GonzÁlez, Repoblación, 1, p. 281.

70 Sobre el castillo de Consuegra pueden consultarse los trabajos de José JimÉNEz NIETO, El castillo de Consuegra, Toledo, 1963; Fernando CASTRo LóPEZ-VILLARINO, Memoria del castillo de Consuegra, Madrid, 1983; Juan Carlos Fernandez-Layos de MiER, El castillo de Consuegra, Toledo, 1984; Idem, "El castillo de Consuegra". Actas del / Congreso de Arqueología Medieval Española, Zaragoza, 1986, V, 217-133; María Olga PÉREz Monzón, "El castillo sanjuanista de Consuegra", Castillos de España, 98 (1989), 31-40; y A. RuiBaL, "El sistema defensivo del priorato de San Juan", en A. Madrid y H. O'Donnell (eds.), Actas de las /I Jornadas de la Orden de San Juan (Arenas de San Juan, abril de 1998). Ciudad Real, 1999, 123-147. 
VIII, que en 1200 concedió a la Orden del Hospital una renta anual de 30 cahices de medida toledana de sal en las salinas de Belinchón para las obras de mantenimiento del castillo de Consuegra ${ }^{71}$. Ese mismo año ampliaba los ingresos señoriales de los sanjuanistas al determinar la protección de todos aquellos que desde Toledo quisieran llevar sus recuas a alAndalus, pagando en Consuegra los derechos correspondientes ${ }^{72}$. El dominio almohade sobre Calatrava propició que Consuegra canalizara todo el portazgo de aquellas recuas que se dirigiesen hacia dominios musulmanes y no sólo las que fueran a tierra de Segura, tal y como se había establecido en $1173^{73}$. En cambio, no conocemos la relación que este hecho pudiera tener con una noticia que data del mismo año 1200, según la cual Alfonso VIII confirmó a la Orden del Hospital, a cambio de tres villas, que no pagase las acémilas que solia pagar ${ }^{74}$.

No era meramente casual la atención hacia Consuegra, la importancia que ésta y la propia Orden hospitalaria habian adquirido en la frontera castellano-andalusí ${ }^{75}$ se vio clara cuando Alfonso VIII realizó testamento en diciembre de 1204. En él se disponía la entrega de 2.000 maravedís durante diez años, por el remedio del alma del rey, para el mantenimiento del castillo de Consuegra. Se indicaba así que, después de Salvatierra

71 El original se ha perdido, pero conservamos el documento a través de una confirmación de Fernando III de 1219. Publ. J. Gonzalez, Alfonso VIII, III, p. 656; P. Guerrero Ventas, El Gran Priorato, pp. 335-336; Libro de Privilegios, n. ${ }^{\circ} 190$. Parece que su contenido responde a la reseña del documento fechado en Toledo, el 29 de diciembre de 1200. Cfr. Biblioteca Nacional, Ms. 714 , fol. 161; J. Delaville, Cartulaire, I, p. 688 (con fecha 30 de enero); J. González, Alfonso VIII, III, p. 860 (señala que por el itinerario la fecha es 29 de diciembre de 1200).

72 Libro de Privilegios, $\mathrm{n} .^{\circ} 191$.

73 En efecto, el 24 de marzo de 1173, Altonso VIII, el maestre de la Orden de Calatrava, Martín Pérez de Siones, y Rodrigo Rodríguez, por entonces señor de Consuegra, acordaron que todas las recuas que fuesen a tierra musulmana pagarían portazgo en Calatrava, excepto las que se dirigiesen a tierra de Segura, que lo darían en Consuegra. Publ. J. GonzÁEZ, Alfonso VIII, II, pp. 297-298; P. Guerrero Ventas, El Gran Priorato, p. 334. Se establecia así que el tráfico comercial por las amplias llanuras manchegas se canalizaría a través de dos puntos: Calatrava y Consuegra. Cuando en 1183 el castillo de Consuegra, con todos sus derechos, pasó a poder de los sanjuanistas es lógico pensar que también adquiriesen con él los derechos de portazgo sobre las recuas.

74 AHN, OO.MM., Indice 176 , fol. $198 \mathrm{r}$

75 Los años transcurridos en la vanguardia fronteriza, durante el dominio almohade del Campo de Calatrava (1195-1212), debieron revalorizar la posición estratégica de Consuegra con respecto a las fortalezas cercanas y a las vias de comunicación que las unían. Así, después de la campaña de Las Navas de Tolosa, todavía se utilizaba la alternativa de Consuegra frente al tradicional paso del camino de Toledo a Córdoba por Guadalerza (sobre el trazado habitual vid. Manuel CORChado SoRIANo, El camino de Toledo a Córdoba, reimpresión, Jaén, 1969). Al menos eso se desprende del hecho de que Alfonso VIII, al ir a asediar Baeza en 1213, pasara por Consuegra, Calatrava y el puerto del Muradal. Vid. Rodrigo JIMÉNEZ DE RADA, Historia de los hechos de España, trad. J.Fernández Valverde, Madrid, 1989, p. 327; Primera Crónica General de España, ed. de R.Menéndez Pidal, con estudio actualizado de D.Catalán, Madrid, 1977, p. 706. 
-a la que se asignó una renta anual de 10.000 maravedís- y Uclés -que recibiría anualmente 4.000 maravedis-, Consuegra constituía la tercera fortaleza en importancia dentro del entramado defensivo castellano. También la Orden de San Juan se situaba, en la mentalidad del monarca, como la tercera Orden militar en Castilla, después de Calatrava y Santiago, al recibir dos novenas partes de las armas, corazas, cotas de malla, cabalgaduras y ballestas del rey ${ }^{76}$.

Por esas mismas fechas, la monarquía castellana se preocupaba también por la organización social del espacio sanjuanista de Consuegra. Así, para atraer pobladores que consolidaran la colonización del territorio fronterizo, probablemente Alfonso VIll concedió a Consuegra una adaptación del fuero de Cuenca ${ }^{77}$, que ya se había mostrado como un eficaz derecho de frontera.

Paralelamente a la atención de la vanguardia fronteriza, nuevas donaciones del monarca reforzaban el patrimonio hospitalario en comarcas más septentrionales del reino de Toledo. En diciembre de 1202 Alfonso VIII cedía a la Orden de San Juan ocho yugadas de heredad en la aldea de Carrano $^{78}$. Un año después donaba a los freires un solar en Toledo con el objetivo de que construyeran allí $\operatorname{casas}^{79}$.

No obstante, un episodio de la guerra castellano-leonesa entre Alfonso VIII y Alfonso IX enturbió las excelentes relaciones entre la Orden del Hospital y la monarquía castellana. En efecto, el rey castellano adquirió

76 La confianza de Alfonso VIII en la Orden se materializó al figurar el prior sanjuanista Gutierre Armíldez como fiador del testamento. En el mismo, además de todo lo señalado, el rey donó al Hospital, por la salud de su alma, los castillos de Villavega y Cabañas, con todos sus derechos. El estudio del testamento en Fidel FITA, «El testamento de Alfonso VIII (1204)", Boletín de la Real Academia de la Historia, 8 (1886), 229-248. La publicación en este trabajo (pp. 230-38) y en J. GonzÁlez, Alfonso VIII, III, pp. 341-47.

77 El texto latino del fuero de Consuegra se ha perdido, pero su contenido se puede reconstruir a través de D. AGuIRre, El Gran Priorato, pp. 201-221, y de las notas y apéndices de $F$. Cerda y Rico a la obra de G. Ibánez de Segovia (MARqués de MondejaR), Memorias históricas de la vida y acciones del rey don Alonso el Noble, octavo del nombre, Madrid, 1783. Un estudio específico del fuero consaburense en P. GUERRERO VENTAS, «El fuero de Consuegra y la Repoblación de La Mancha", Provincia de Toledo, XII, 54 (1966), sin paginar; Idem, El Gran Priorato, pp. 67-84. Sobre las relaciones con los fueros de Cuenca y Alcázar vid. Ana María Barrero y María Luz ALonso, Textos de derecho local español en la Edad Media. Catálogo de fueros y costums municipales, Madrid, 1989, pp. 105-106, 208 y 216-217; Ana Maria BARRERo GarciA, «La familia de los fueros de Cuenca", Anuario de Historia del Derecho Español, 46 (1976), 713-725; Idem, "El proceso de formación del fuero de Cuenca", Anuario de Estudios Medievales, 12 (1982), 41-58; R. de Ureña SMenjaud, Las ediciones del fuero de Cuenca, Madrid, 1917; Idem (ed.), Fuero de Cuenca, Madrid, 1935.

78 Libro de Privilegios, $\mathrm{n} .^{\circ} 192$.

79 lbid., n. 193. 
por la fuerza los castillos de Fresno y Paradinas y las villas de Torrecilla, Tarazona y Porta, todas ellas propiedades sanjuanistas en el reino leonés ${ }^{80}$. En estas circunstancias desfavorables para la Orden se pusieron de manifiesto, una vez más, los fuertes lazos de unión entre el papado y los hospitalarios. En enero de 1206 el papa Inocencio III ordenó al arzobispo de Toledo Martín López de Pisuerga y al obispo de Zamora Martín Arias que obligasen a Alfonso VIII a devolver las propiedades sanjuanistas arrebatadas por la guerra ${ }^{81}$. Un año después el propio pontífice romano volvia a incentivar la acción fronteriza de la Orden hospitalaria al concederle licencia para construir villas, iglesias y cementerios en lugares yermos, y preferentemente en la zona de frontera con los musulmanes ${ }^{82}$.

Sin embargo, a pesar del conflicto antes reseñado, las relaciones con la monarquía castellana, como no podía ser de otra manera, retomaron su pulso normal, por necesaria confluencia de intereses comunes. Así, en marzo de 1208, desde Burgos, Alfonso VIII confirmaba a la Orden del Hospital y a su prior todas las heredades adquiridas en su reino ${ }^{83}$.

La consolidación del patrimonio señorial sanjuanista en la frontera se completó con compras a particulares. En 1209 Vela García vendió a la Orden del Hospital todas sus heredades, casas, baños, hornos, molinos, viñas y huertos en Toledo y Algorfiella por 350 maravedís ${ }^{84}$. Unos años después la Orden compró a doña María Cristóbal una aldea y una heredad en Maqueda por 150 maravedís ${ }^{85}$. Por fin, en 1214 los hospitalarios dirigieron su atención más al sur, al comprar una huerta en Talavera al prior de Valdeiglesias por 50 maravedís ${ }^{86}$. En la misma fecha Elvira Gómez donó a la Orden del Hospital una heredad en Polvoranca ${ }^{87}$.

Después de la campaña de Las Navas de Tolosa (1212), donde se constata la intervención activa de los hospitalarios ${ }^{88}$, la frontera castellanoandalusí se restableció en Sierra Morena. La Orden de San Juan pudo

\footnotetext{
80 J. Gonzalez, alfonso VIII, I, p. 736.

81 Publ. J. Delaville, Cartulaire, II, pp. 57-58; D. MANSILla, La documentación pontificia hasta Inocencio III (925-1216), Roma, 1955, pp. 353-354.

82 Publ. J. Delaville, Cartulaire, II, p. 63; D. Mansilla, Inocencio III, pp. 380-381.

83 AHN, OO. MM., carp. 568, n. ${ }^{\circ}$ 3. Publ. J. GonZALEZ, Alfonso VIII, III, pp. 440-441.

${ }^{84}$ Libro de Privilegios, $\mathrm{n} .^{\circ} 203$.

85 lbid., n. ${ }^{\circ} 209$.

Be lbid., n. ${ }^{\circ} 211$

87 lbid., n. 214 . La donación era interesante para la Orden por la proximidad a la encomienda sanjuanista de Humanes, donde presumiblemente se integraría esta nueva heredad.

${ }_{88}$ Los freires del Hospital participaron, junto con los del Temple, Calatrava y Santiago, en el núcleo central del ejército cristiano. Vid. R. JiménEZ DE RADA, Historia de los hechos de España, trad. cit., pp. 310 y 319-320.
} 
demostrar entonces hasta donde alcanzaba la proyección de su señorío fronterizo en La Mancha. En junio de 1215 Enrique I concedió a los hospitalarios que sus castillos de Peñarroya, Santa María, Villacentenos y Ruidera, situados en la cuenca alta del Guadiana, tuvieran dehesas bien acotadas $^{89}$. El documento demuestra que la Orden habia alcanzando muy pronto el límite meridional del futuro Campo de San Juan. La colonización activa de este espacio tendría lugar en las décadas sucesivas. Más al sur todavía, en Alcaraz, que había sido conquistado por los castellanos en 1213, el merino regio Pedro Fernández, por mandato de Alfonso VIII, donó a los hospitalarios las casas, viña, huerta, molino y heredad de Cortes, propiedades confirmadas por el monarca castellano en julio de $1214^{90}$.

\section{LA PRIMITIVA RED COMENDATARIA SANJUANISTA EN EL REINO DE TOLEDO}

La primitiva organización administrativa de la Orden en el Occidente peninsular no se refleja con claridad en la documentación que los investigadores pueden manejar. El profesor Carlos de Ayala ha planteado como hipótesis razonable la independencia inicial de los hospitalarios castellanoleoneses respecto al priorato de Saint Gilles ${ }^{91}$. De tal suerte que el prior Martín, que se documenta en 1135 actuando en el ámbito castellanoleonés tendría unas competencias territoriales que sustancialmente se identificarían con el reino occidental, aunque su titulación no aparezca vinculada a ningún ámbito geográfico concreto ${ }^{92}$. Posteriormente, el priorato sanjuanista de Castilla y León pasó a denominarse priorato de Hispania. Probablemente, detrás de la denominación subyacía el deseo de ejercer una cierta primacía sobre el resto de los territorios hispánicos, intentando reflejar la superioridad política que se reconocía al imperio de Alfonso VII y aprovechando la inexistencia de estructuras autónomas similares en otros ámbitos peninsulares. El proceso de denominación del priorato castellano-

B9 Libro de Privilegios, $\mathrm{n},{ }^{\circ} 215$.

90 lbid., n. 210.

91 Carios de Ayala Martinez, "Orígenes e implantación de la Orden de San Juan de Jerusalén en la Península Ibérica (siglo xil)", en R. Izquierdo, F. Ruiz y J. Molero, eds., La Orden Militar de San Juan en la Peninsula lbérica durante la Edad Media. Actas del Congreso Internacional celebrado en Alcázar de San Juan los dias 23, 24 y 25 de octubre de 2000, Alcázar de San Juan, 2002, 23-41, pp. 30-33. Sobre el tema de la primitiva organización administrativa vid. también del mismo autor su trabajo sobre «La Orden militar de San Juan en Castilla y León. Los hospitalarios al norte del Sistema Central (siglos XII-XIV)", Historia. Instituciones. Documentos, 26 (1999), 1-40, pp. $2-5$.

92 Libro de Privilegios, n. 35. 
leonés como priorato hispánico se había iniciado algunos años antes - ya la mencionada donación de Olmos en 1144 era recibida por Quessardo, eius Hospitalis per Hispaniarum priori constituto- y quedó consolidado a principios de la década de 1160 , bajo el priorato de frey Villano ${ }^{93}$.

El incremento patrimonial experimentado en el reino de Toledo durante las décadas de 1160,1170 y 1180 , y, sobre todo, la donación de Consuegra, hicieron aconsejable dar los primeros pasos hacia lo que sería la futura división del priorato de Hispania. El hecho responde más a operativas razones geográficas, encaminadas a un más adecuado control del patrimonio, que a determinantes motivos políticos. Según Aguirre la división del priorato hispánico se produjo a la muerte de Alfonso $\mathrm{VII}{ }^{94}$, pero tal reparto no se refleja inequívocamente en la documentación hasta comienzos del siglo XIII ${ }^{95}$.

Sin embargo, el proceso parece haberse iniciado antes, al menos a partir de febrero de 1185. Entonces aparece documentado un comendator citra serram, que desde Consuegra presidía el Capítulo de la Orden encargado de gestionar sus señoríos en la Meseta meridional ${ }^{96}$. En junio de ese mismo año Rodrigo Rodríguez, comendator, una cum universo Capitulo Hospitali citra serram, recibió una donación realizada por Martín Pérez de Camarena y su mujer Dominga ${ }^{97}$. Naturalmente, la jurisdicción del prior hispánico permanecía por encima de la de estos comendadores transerranos.

El núcleo de esta embrionaria organización administrativa se situaba en la fortaleza de Consuegra, convertida en sede de la encomienda hospitalaria más importante de todo el reino de Toledo y en cabeza de una incipiente estructura que englobaría a todas las encomiendas de la Orden situadas al sur del Sistema Central. Por eso, a partir de 1187, los freires con jurisdicción sobre el señorío hospitalario del reino de Toledo comienzan a aparecer en la documentación bajo la denominación de comendadores de Consuegra. Ese mismo año, Melendo Díaz, comendador de Consuegra, e todo el convento de aquende sierra, tuvo potestad suficiente para fijar el nuevo censo que debían pagar a la Orden los pobladores de Villamiel ${ }^{98}$. Posteriormente, la documentación apenas nos permite recoger el nombre de algunos freires que estuvieron al frente de la encomien-

93 Figura como prior hospitalario de Hispania en documentos de 1161 (Libro de Privilegios, $n .^{\circ}$

86), 1162 (AHN, OO.MM., carp. 455, n. ${ }^{5}$ ) y 1163 (Libro de Privilegios, $n .{ }^{\circ} 91$ ).

94 D. AguirRe, El Gran Priorato, p. 185.

95 C. Ayala Martinez, "La Orden de San Juan en Castilla y León", pp. 4-5.

96 Libro de Privilegios, n. 155 y 156.

97 Ibid., n. 156.

$98 \quad$ lbid. n. ${ }^{\circ} 158$. 
da consaburense: Sancho (1198), Montesino (1208-1210) ${ }^{99}$, Rodrigo Morici (1209), Roy Muñoz (1212?) y Gutierre Armíllez (1216). Este último es el único de estos comendadores consaburenses que vuelve a identificarse expresamente con una jurisdicción transerra: de todas las cosas del Hospital en toda Trassierra comendador mayor (mayo de 1216) o comendador en Consuegra e aquen Sierra (noviembre de 1216) ${ }^{100}$.

Al margen de la encomienda de Transierra-Consuegra, la primera de las encomiendas sanjuanistas en la Meseta meridional fue la de Villamiel. Su comendador García aparece como testigo de un documento de febrero de 1185, a través del cual el prior Pedro Arias autoriza a los pobladores de Villamiel a construir un molino a cambio de percibir la mitad de sus rentas ${ }^{101}$. Dos años después, la encomienda de Villamiel estaba ocupada por Pedro Aimar, que estuvo presente cuando el comendador de Consuegra rebajó el censo que debian pagar los pobladores de Villamiel ${ }^{102}$. Se trata, por otra parte, de las primeras menciones a comendadores relacionados con propiedades sanjuanistas del reino de Toledo; una aparición que es prácticamente contemporánea a la de los primeros comendadores que se documentan en la Meseta septentrional ${ }^{103}$.

Ese mismo año de 1187 se documentan dos nuevas encomiendas: Toledo, al frente de la cual figura don García, y Tajuña, a cuya cabeza estaba don Arnaldo ${ }^{104}$. Un lustro después, para 1192, ya se había constituido la encomienda hospitalaria de Talavera, con centro en una casa de esta villa. Su comendador Pedro de Lamas, junto a los freires Juan Bravo y Alfonso Díaz, compró a doña Águeda la aldea de Pedro Pérez el Tuerto ${ }^{105}$. Un año después, el comendador Pedro de Lamas, con los dos freires sanjuanistas mencionados, adquirió a Pedro Cañadilla las casas, viñas, tierras, prados y otros bienes que tenía en la aldea de Cañadilla por quince maravedís ${ }^{106}$.

99 RAH, col. Salazar, sign. M-59, fols. 164r-166v. Publ. C. BARQuero Goñ, Los hospitalarios en Castilla y León [siglos xil y xill]. Señorios de la Orden de San Juan, doc. 272. El documento está fechado en 1157, pero el editor explica que los personajes que figuran en el mismo sólo fueron contemporáneos entre 1208 y 1210 . Probablemente se trata del mismo don Montesino, freire de la Orden del Hospital, que en 1214 se documenta como delegado regio en la repoblación de Alcaraz. Su huelia quedó reflejada en la toponimia de un molino que marcaba el término de Quero y una cueva cercana a las lagunas del Guadiana. Vid. J. GonzÁLeZ, Alfonso VIII, III, n. $968 ;$ y J. GONZÁLEZ, Repoblación, I, pp. 261-262

100 Libro de Privilegios, n. 218 y 220.

101 lbid., n. 155.

102 lbid., n. 158.

103 C. Ayala Martínez, «La Orden militar de San Juan en Castilla y León», pp. 5-6.

104 Libro de Privilegios, n. ${ }^{\circ} 158$.

105 Ibid., n. ${ }^{\circ} 176$.

106 Ibid., n. 177. 
A principios de la década de 1190 se completa la primera fase del incipiente proceso de creación de encomiendas. Se abre entonces un paréntesis en el ritmo del crecimiento comendatario en el reino de Toledo que no es desvinculable del recrudecimiento de la ofensiva almohade ni tampoco de la necesaria asimilación paulatina de una organización que todavía estaba dando sus primeros pasos y distaba mucho de reflejar una completa red territorial del patrimonio de la Orden. En esa primera fase, que se documenta cronológicamente entre 1185 y 1192, se habían constituido cinco encomiendas: Transierra-Consuegra, Villamiel, Toledo, Tajuña y Talavera.

Más de tres lustros habrían de transcurrir para que surgieran nuevas encomiendas en el reino de Toledo. Esta segunda fase se materializa también documentalmente a lo largo de un período de siete años, los que van de 1209 a 1216, en el transcurso de los cuales se documentan otras cinco encomiendas ${ }^{107}$.

Así hacia 1209 aparece la encomienda de Humanes, al frente de la cual estaba Rodrigo Morici ${ }^{108}$. La encomienda de Molina, situada en un señorío independiente enclavado en la frontera castellano-aragonesa, se constituyó muy probablemente a principios del siglo XIII. En noviembre de $1211 \mathrm{el} \mathrm{mo-}$ narca aragonés Pedro II concedió al comendador hospitalario de Molina, al que califica de dilecto nostro, enfranquecimiento, libertad e inmunidad para él, los freires, los habitantes de Torre de la Junta y los ganados de la encomienda sanjuanista ${ }^{109}$. Tal vez en junio de 1212, Pedro Ballestero, comendador de Olmos, compró a María Cristóbal una aldea y heredad en término de Maqueda, cerca de la heredad que ya poseían los freires sanjuanistas, además de unas tierras próximas al molino del herrero por 150 maravedís ${ }^{110}$. Finalmente, al Capítulo de la Orden reunido en Wamba en 1216 acudieron Pedro Martín de Salas, comendador de Cedillo, Juan Ballestero, comendador de Olmos, y frey Montesino, comendador de Peñarroya ${ }^{111 .}$

107 En un documento de abril de 1203 aparece el comendador don García Ruiz actuando junto al prior Gutierre Armildez en una avenencia sobre derechos en Villamiel. Podría tratarse del comendador de esta aldea toledana o de Consuegra. Vid. C. Torroja MEnÉndez, Catálogo del Archivo del monasterio de San Clemente de Toledo (1141-1900), Toledo, 1973, p. 23.

108 Libro de Privilegios, $n .^{\circ} 200$.

109 lbid., n. 207. Se han apuntado dudas sobre la identificación de este topónimo con la actual localidad de Molina de Aragón (C. BAROUERo Goñı, Los hospitalarios en Castilla y León lsiglos XII y xIII], p. 744). Sin embargo, la inclusión del documento en el Libro de Privilegios de los hospitalarios castellanoleoneses, la intervención de Pedro II de Aragón en un señorío independiente situado en la frontera castellanoaragonesa y la datación del documento en Daroca, una villa muy próxima a Molina de Aragón, apuntan a la identificación del topónimo que aparece en el documento de 1211 con la actual localidad castellanomanchega, cabeza del señorío de Molina.

110 Libro de Privilegios, n. 209.

111 lbid., n. 218. 
En esta segunda fase, dos de las cinco primeras encomiendas, las de Villamiel y Tajuña, han desaparecido de la documentación, hecho que debemos interpretar como consecuencia de la indefinición institucional y la inmadurez de estas primitivas circunscripciones ${ }^{112}$. En cambio se mantienen, además de Consuegra, las encomiendas hospitalarias situadas en los dos concejos de realengo más importantes de la región: Toledo y Talavera. Así, en julio de 1214 el prior del monasterio de Valdeiglesias vendió a frey Martín, comendador hospitalario de Talavera, una huerta en término de la citada villa por 50 maravedís ${ }^{113}$. Este último comendador, junto con el toledano Martín Vicente, asistió al ya citado capítulo de Wamba (1216).

\section{CAUCES PARA LA ADQUISICIÓN DEL PATRIMONIO SANJUANISTA}

Del análisis de la documentación sanjuanista se desprende que el cauce fundamental para la adquisición del patrimonio señorial sanjuanista en el reino de Toledo fueron las donaciones. En esto la Orden del Hospital se diferencia bien poco de los restantes señoríos eclesiásticos.

Las donaciones se iniciaron con buenos augurios durante el reinado de Alfonso VII y continuaron a buen ritmo a lo largo de la segunda mitad del siglo XII, hasta alcanzar su paroxismo en la década de 1180, correspondiente a la etapa final del priorato de Pedro Arias. En los últimos años del siglo xII la presión almohade detuvo el crecimiento de las donaciones, por lo que la Orden tuvo que acudir por primera vez a las compras. Durante los primeros años del siglo XIII, la reorganización fronteriza frente a la ofensiva islámica derivó en un retorno de las donaciones, pero ya en convivencia con las compras iniciadas en el período anterior.

Por lo que se refiere a la procedencia social de los donantes se pueden distinguir tres grupos: rey, magnates y pequeños propietarios. En este contexto, se constata que las donaciones provienen en un porcentaje mayoritario de la iniciativa real. Ésta es particularmente importante en las fases iniciales de acumulación del patrimonio señorial sanjuanista y en los primeros años del siglo XIII. A partir de 1168 la nobleza se incorporó a la di-

\$12 El proceso se observa también en la fase de formación de las primitivas encomiendas de las órdenes militares hispánicas. Vid. C. AYALA MARTinEZ, "Comendadores y encomiendas. Origenes y evolución en las órdenes militares castellano-leonesas de la Edad Media", en 1. Fernandes, ed., Ordens Militares: guerra, religião, poder e cultura. Actas do III Encontro sobre Ordens Militares, Lisboa-Palmela, 1999, I, 101-147, pp. 104-117.

${ }^{113}$ Libro de Privilegios, $n .^{\circ} 211$ 
námica regia de donaciones fronterizas a la Orden del Hospital. Las donaciones de tipo particular -ya sean de nobles o de otros personajescontinuaron durante todo el período que estamos analizando, hasta comienzos del siglo XIII.

Sin embargo, las ventas a los sanjuanistas, al contrario que las donaciones, procedieron en su totalidad del patrimonio particular. Tan sólo hemos podido determinar la condición social de uno de los vendedores. Se trata del prior de Valdeiglesias, que actúa en representación del abad don Ostenz y todo el cenobio cisterciense. En cualquier caso, ambos personajes, en su condición de relevantes eclesiásticos, se asimilan al grupo de la aristocracia.

En relación a la tipología de los bienes adquiridos, constituyen prácticamente la mitad de los mismos pequeñas heredades, casas, huertas y otras propiedades asimilables. Entre ellos se incluye también la iglesia de Santa Cruz en Toledo, pues en realidad es una casa religiosa de la Orden. Estos bienes proceden en su mayoría del cauce de adquisición particular, aunque en ocasiones también se debieron a donaciones de la monarquía.

No son desdeñables tampoco los lugares fronterizos en los que, a lo largo del siglo XII, la Orden del Hospital ejerció su señorío. Más de una docena entre castillos, villas y aldeas. Su adquisición, siempre de la mano de la monarquía o la nobleza, procede de las primeras etapas y, si exceptuamos el caso de las fortalezas manchegas más meridionales, ya estaba completada en 1183.

Otro tipo de bienes muy apreciados por los sanjuanistas fueron los monopolios de teórica jurisdicción real o señorial como hornos, molinos, tiendas, baños y salinas, que la Orden consiguió lógicamente por mediación de la monarquía o la nobleza.

Finalmente, se sitúa el capítulo de las rentas extraordinarias procedentes de la Corona. La Orden las recibió en los años de tránsito entre los siglos XII y XIII, fundamentalmente para sustentar económicamente la fortaleza de Consuegra, cuya importancia había aumentado en la nueva reorganización fronteriza castellana.

\section{GEOGRAFIA DEL PATRIMONIO SANJUANISTA EN EL REINO DE TOLEDO}

La geografía del patrimonio sanjuanista del reino de Toledo se concentra, con algunas excepciones puntuales, en cinco ámbitos geográficos: 
La Alcarria, la tierra llana de Madrid, La Sagra, el sector occidental del reino de Toledo y La Mancha. Entre ellas sobresalen por la relevancia y el número de las propiedades La Mancha, La Sagra y La Alcarria. Por otra parte, conviene distinguir muy bien los lugares en los que la Orden disfruto del señorío de aquellos otros donde sólo tenía propiedades. Los más interesantes para los hospitalarios eran los primeros, ya que determinan la mayor o menor importancia de las diferentes comarcas en el contexto del señorío sanjuanista. Las villas eran los núcleos más codiciados por la Orden al tener bajo su jurisdicción un territorio dependiente. Así el Hospital disfrutó, en el período que estamos analizando, del señorío sobre las villas de Olmos, Consuegra, Criptana, Ajos, Quero y Tirez. Además los hospitalarios se hicieron también con el señorío sobre las aldeas de Peñalver, Alhóndiga, Humanes de Madrid, Villamiel de Toledo y Pedro Pérez el Tuerto.

\subsection{La Alcarria y las tierras limítrofes}

La primera de las posesiones alcarreñas de la Orden fue la aldea de Peñalver, situada en el alfoz de Guadalajara. A mediados del siglo XII, el concejo de Guadalajara donó esta aldea al Hospital. No obstante, según la versión ofrecida por el primitivo fuero de Peñalver, fue el propio emperador Alfonso VII el que intervino en la cesión de la aldea a los sanjuanistas. En cualquier caso, desconocemos la fecha exacta de la donación de Peñalver a la Orden. Su cronología se encuentra estrechamente ligada con la del fuero de la aldea, ya que en ambos documentos aparecen el mismo juez - Vicente Ferruz- e idéntico sayón -Aster- en Guadalajara, además de coincidir varios testigos. En consecuencia, cabe concluir que tanto la donación como el fuero de Peñalver están fechados en el mismo año. El ordenamiento foral indica claramente que su entrega se produjo durante el reinado de Alfonso VII, con la confirmación de sus hijos Sancho y Fernando, que figuran ya como reyes ${ }^{114}$. Por lo tanto, cabe situarlo en la última década del reinado del emperador castellano-leonés (1148-1157), cuando el infante Fernando empieza a figurar asiduamente como rey-confirmante de los documentos paternos. En cualquier caso, en el transcurso

114 Libro de Privilegios, n. ${ }^{\circ} 76$ y 77 . La redacción del texto y sus numerosas interpolaciones no contradicen su primitivo origen. Se trata, en cualquier caso, de cuestiones formales motivadas por el hecho de que la copia que conservamos está contenida en un documento confirmatorio de 1284 que no sigue una transcripción literal a partir del original. Las similitudes entre el fuero de Peñalver y el de Alhóndiga (1170) reafirman la hipótesis de una relativa proximidad cronológica entre ambos. 
de la década de 1170, la aldea de Peñalver fue definitivamente confirmada a la Orden de San Juan por Alfonso VIII ${ }^{115}$.

Muy próxima a la aldea de Peñalver, aunque ya en el alfoz de Zorita, se situaba la aldea de Alhóndiga. Parece ser que allí la iniciativa correspondió a los freires hospitalarios, poco antes de que la tierra de Zorita pasara a señorío calatravo en 1174. En efecto, cuatro años antes, el prior Juan concedió a los pobladores de Alhóndiga un fuero de notables concomitancias con el de Peñalver y con frecuentes alusiones al fuero latino de Huete ${ }^{116}$. La concesión del ordenamiento foral contó con la aprobación del prior mayor Pedro Arias. Sin embargo, la organización del espacio agrario se había iniciado antes, a través de la modalidad de repartir las tierras a quiñón, equivalente aproximadamente a una yugada de heredad. El fuero ofrece el nombre de tres de estos quiñoneros que formaban parte del concejo de Alhóndiga y de otros cinco individuos que presumiblemente también lo eran ${ }^{117}$.

También en la comarca de La Alcarria ${ }^{118}$, más al este que las dos aldeas anteriores, la Orden del Hospital contaba con heredades en Alcocer, que habian sido donadas por los hijos de Nuño Núñez en $1203^{119}$.

En las tierras conquenses, entre el curso alto del Tajo y su afluente el Guadiela, la Orden recibió de Alfonso VIII (1184) salinas, huertos y otros bienes en Beteta ${ }^{120}$. En la misma donación el monarca incluyó viñas, huertos, molinos y otras heredades situadas en diversos lugares del término de Cuenca ${ }^{121}$.

115 Ibid., n. ${ }^{\circ}$ 102. El documento está fechado en 1168, pero en él aparece la reina Leonor, cuyo matrimonio con Alfonso VIll no tuvo lugar hasta dos años después. En consecuencia hay que retrasar la datación hasta la década de 1170 .

${ }_{116}$ Un extracto del contenido de este fuero en Plácido BALLESTEROS SAN Jose y Ricardo Murillo Murillo, Aproximación histórica a la Alcarria Baja. Tierra de Zorita y Almoguera, Guadalajara, 1985, pp. 194-195.

117 E. Hinojosa, Documentos, p. 77.

${ }_{118}$ Las frecuentes alusiones a la figura del comendador que contiene el primitivo fuero de Peñalver deben interpretarse como interpolaciones posteriores, ya que la versión que ha llegado hasta nosotros está contenida en un documento confirmatorio de 1284 que no parece seguir una transcripción literal a partir del original (Libro de Privilegios, $n .77$ ). De lo contrario, tendriamos que admitir la existencia de una encomienda sanjuanista en el reino de Toledo una treintena de años antes de la creación del sistema de encomiendas de la Orden en esta región. Tal hipótesis parece muy poco probable. La primera mención documental al comendador de Peñalver se remonta a 1229 (ibid., n. 249)

${ }_{119}$ El documento se encontraba extractado en la RAH, col. Salazar, sign. 9-1084, fol. 157. Cfr. A. Vargas-Zúniga y B. Cuartero Y Huerta, índice de la colección de don Luis Salazar y Castro, 49 vols., Madrid, 1949-1979, vol. XL, p. 267.

120 En el marco de la repoblación de las tierras conquenses, Beteta pertenece a su primera etapa. Alfonso VIII dio su iglesia, con las heredades, salinas y villares cercanos a la catedral de Sigüenza. Vid. J. GonzAlEz, "Repoblación de las Tierras de Cuenca», Anuario de Estudios Medievales, 12 (1982), p. 186; Idem, Alfonso VIII, II, doc. 90.

121 Libro de Privilegios, $n .^{\circ} 154$. 
En las estribaciones meridionales del Sistema Central se situaba la comunidad de Villa y Tierra de Atienza, donde los sanjuanistas tenían un oratorio que planteó problemas de jurisdicción eclesiástica con el obispo de Sigüenza. La solución al conflicto llegó en mayo de 1200, cuando el papa Inocencio III mandó al obispo consagrar el oratorio de la Orden ${ }^{122}$.

Finalmente, en tierras limítrofes a la Alcarria, las del señorío independiente de Molina, la Orden del Hospital contaba con la casa del comendador en la propia villa de Molina, la cabaña ganadera asociada y la Torre de la Junta ${ }^{123}$.

\subsection{La tierra llana de Madrid}

La tierra llana de Madrid, que se extiende desde la rampa de erosión del Sistema Central hasta los páramos alcarreños y la cuenca del Tajo y el Henares ${ }^{124}$, fue también territorio que despertó una temprana atención entre los hospitalarios.

En febrero de 1141 Alfonso VII había donado a Pedro Brimón la villam medio desertam quam dicunt Humanes, que iacet inter Majerido et Toletum ${ }^{125}$. Posteriormente, la villa pasó a manos de Pelayo Pérez de Frómista, quien en enero de 1176 la donó a la Orden del Hospital, excepto illud quod teneo ad laborem boum meorum y la condición de que la mitad de la misma la tuviera su mujer doña Urraca con carácter vitalicio ${ }^{126}$. Una vez que los freires sanjuanistas se hicieron con el control de toda la villa de Humanes, el prior Pedro Arias decidió cederla vitaliciamente al conde don Fernando Núñez de Lara ${ }^{127}$, quien en 1193 la devolvió a la Orden a cambio de 714 maravedís ${ }^{128}$.

Los bienes sanjuanistas en Humanes se incrementaron en febrero de 1198, cuando doña Columba y su marido García Fánez vendieron a los freires hospitalarios una heredad en la aldea por 40 maravedís ${ }^{129}$. A prin-

${ }_{122}$ T. Minguella y Arnedo, Historia de la diocesis de Sigüenza, I, pp. 507-508; D. Mansilla, Inocencio III, p. 260.

${ }_{123}$ Libro de Privilegios, n. ${ }^{\circ} 207$.

124 M. TeRÁn y L. Solé SABARIS, Geografia regional de España, Barcelona, 1978, p. 187.

125 Libro de Privilegios, $n .{ }^{\circ} 46$.

126 Ibid., n. 123

127 En 1183 Alfonso VIII confirmó la cesión realizada por el conde Fernando Núñez de Lara a la Orden de la villa de Villo a cambio de la tenencia vitalicia de las villas de Torre de Herrin y Humanes. Vid. Biblioteca Nacional, ms. 714, fol. 132r; RAH, col. Salazar, sign. O-3, fols. 137v138r. ¿Es posible identificar el topónimo Villo con la localidad toledana de Lillo?

${ }_{128}$ Libro de Privilegios, n. ${ }^{\circ} 180$.

129 Ibid., n. ${ }^{\circ} 187$. 
cipios del siglo XIII —probablemente en enero de 1209- el prior Gutierre Armíldez concedió fuero a los habitantes de Humanes, estando presentes los dos alcaldes, el juez y el concejo de esta localidad ${ }^{130}$. Más al norte, ya en los límites del alfoz de Madrid, estaba la heredad que en 1214 donó Elvira Pérez en Polvoranca ${ }^{131}$.

Hacia al este, en la ribera del Tajuña, y en el territorio perteneciente jurisdiccionalmente al concejo segoviano, se situaban varias propiedades sanjuanistas, cerca del límite con el término de Alcalá de Henares, y al oeste por tanto de la aldea de Perales de Tajuña. Allí estaban los molinos que Alfonso VII había donado al conde Manrique Pérez de Lara y que su mujer la condesa doña Ermesinda cedió a la Orden de San Juan en marzo de 1168 , en el locum quem dicunt Molinos de Comite Almerico ${ }^{132}$. Muy cerca, también sobre la ribera del Tajuña, se localizaban las cuatro yugadas de heredad de "año y vez» que Alfonso VIII otorgó a los freires hospitalarios en marzo de 1182, con el beneplácito del concejo de Segovia ${ }^{133}$. La intervención del concejo serrano demuestra claramente que las tierras donadas se encontraban en el ámbito de su término jurisdiccional.

\subsection{La Sagra y las tierras limitrofes}

La comarca toledana de La Sagra se distingue actualmente de la comarca de Torrijos, situada al oeste del Guadarrama ${ }^{134}$. En cambio en el

${ }^{3} 0$ Ibid., n. ${ }^{\circ}$ 200. Sobre esta aldea madrileña vid. C. BARQUERO GOÑI, «La organización sociai del espacio entre Madrid y Toledo: el ejemplo de Humanes de Madrid durante los siglos X\| y XIII" en C. Segura Graiño, ed., Origenes históricos de la actual comunidad autónoma de Madrid. La organización social del espacio en la Edad Media I, Madrid, 1995, 75-90; y C. BARQuero Goñi e I. Redondo AlCAIDE, «Humanes S. X $\|$-XII» y «El ordenamiento juridico" en I. Redondo, Humanes de Madrid desde su Historia, Humanes de Madrid, 1997, 69-90.

${ }_{31}$ Libro de Privilegios, $n .{ }^{\circ}$ 214. Según Madoz (Diccionario, voz Polvoranca), villa agregada al ayuntamiento de Leganés, partido de Getafe, provincia de Madrid. Su localización actual como Parque de Polvoranca en el Mapa de la Comunidad de Madrid, Escala 1:200.000; Mapa Topográfico Nacional (en adelante M.T.N.), Hoja 582. En época medieval Polvoranca estaba incluida en los límites del alfoz de Madrid. Cfr. G. MARTínez DiEZ, “Estructura administrativa local en el naciente reino de Toledo", Actas del // Congreso Internacional de Estudios Mozárabes. Estudios sobre Alfonso VI y la Reconquista de Toledo, II, Toledo, 1988, 43-162, p. 91.

132 Libro de Privilegios, n. ${ }^{\circ} 100$. Tal vez su localización más precisa pueda relacionarse con el topónimo Valdemolinos, que todavía se conserva en la zona septentrional del término municipal de Chinchón, cerca del límite de Morata de Tajuña y, en consecuencia, próximo a la antigua frontera que separaba los términos de los concejos de Alcalá y Segovia. Vid. Mapa de la Comunidad de Madrid. Escala 1:200.000.

133 Libro de Privilegios, $\mathrm{n} .{ }^{\circ} 141$.

134 La delimitación actual de La Sagra en V. Rodriguez Rodríguez, Notas sobre la historia y geografía de La Sagra, Toledo, 1983, pp. 6-9. 
siglo XII las relaciones entre esas tierras eran muy estrechas y no existía una separación tan clara, ya que la mayor parte de ellas pertenecían al alfoz toledano.

La primera y más importante posesión hospitalaria en esta zona se remonta a 1144, cuando Alfonso VII donó a la Orden de San Juan el castillo de Olmos, con todos sus términos ${ }^{135}$, que incluían las aldeas de Carranque ${ }^{136}$, Cedillo del Condado, Palomeque y El Viso de San Juan, y otros lugares actualmente despoblados ${ }^{137}$. No parece que con la donación de Olmos (1144) se incluyese la aldea de Cedillo, pues en 1152 todavía pertenecía al conde Manrique Pérez de Lara, que le otorgó carta de población ${ }^{138}$. En cualquier caso, a principios del siglo xIII la actual Cedillo del Condado pertenecía ya al Hospital. En 1211, ante el portal de su iglesia - de propiedad sanjuanista-, el señor de Albarracín, Pedro Fernández de Azagra, llegó a un acuerdo con el comendador santiaguista García González y el maestre Pedro Arias, en presencia de Alfonso VIII, sobre la donación del castillo de Albarracín, tal y como había dispuesto su padre Fernando Ruiz de Azagra ${ }^{139}$. Probablemente también en los términos de Olmos estaban las ocho yugadas de heredad en Carrano -en el caso de que admitiésemos su probable identificación con Carranque--, donadas por Alfonso VIII a la Orden en diciembre de $1202^{140}$.

Ya en el alfoz de Toledo, se encontraba la aldea de Camarena, donde Martín Pérez y su mujer Dominga entregaron en 1185 toda su heredad a los sanjuanistas, con retención de usufructo vitalicio y su entrega personal a la Orden del Hospital ${ }^{141}$. En el arroyo de Renales, al norte de Villamiel de Toledo y lindante con Camarena y la alquería de Argance, se encon-

135 Libro de Privilegios, $n .^{\circ} 51$. Los intentos del concejo segoviano por hacerse con el control de Olmos y su tierra -a pesar de la donación del castillo recibida de Alfonso VIll en 1166 (J. GONZÁLEZ, Alfonso VIII, II, n. 83) - no fructificaron. Tal vez en relación con esta cuestión puede ponerse la noticia de dos privilegios de 1166 a favor de la bailia de Olmos, que no sabemos en qué medida repercutieron en la ampliación de la donación inicial de 1144 . Vid. P. Guerrero VENTAS, El archivo prioral-sanjuanista de Consuegra. Resumen de sus fondos documentales, Toledo, 1985 , p. 132.

${ }_{136}$ Al parecer el primitivo emplazamiento de Carranque no fue el actual sino el de un despoblado denominado Carranque de Yuso. Vid. P. MADOz, Diccionario, voz Carranque.

137 Sobre los términos del castillo de Olmos, coincidentes aproximadamente con los del señorio sanjuanista, vid. G. MARTinEz DiEz, "Estructura administrativa», pp. 92-95.

138 Conde de CeDillo, "Carta-Puebla de Cedillo", Boletín de la Real Academia de la Historia, 73 (1918), pp. 114-115; F.J. HeRnÁnDEZ, Los Cartularios de Toledo. Catálogo documental, $2^{a}$ edición, Madrid, 1996, n. ${ }^{\circ} 86$.

139 Publ., entre otros, M. Rivera Garretas, La encomienda, p. 279.

140 Libro de Privilegios, n. 192.

141 Ibid., n. ${ }^{\circ} 156$. 
traba la aldea de Algorfiella ${ }^{142}$, donde en septiembre de 1209 los sanjuanistas compraron a Vela García y a su mujer Urraca Garcíez una heredad con casas, viñas, prados, montes, fuentes y molinos ${ }^{143}$.

Más al sur, pero también en el término de Toledo, la aldea de Villamiel fue una de las primeras propiedades en la frontera castellano-andalusí que la Orden del Hospital recibió por donación de la nobleza castellana. En concreto fue el conde don Gonzalo quien en junio de 1168 la entregó a los sanjuanistas y a su prior Regnaldi de Cuaramontano ${ }^{144}$. Dos años después la condesa doña Elvira cedía a la Orden de San Juan la misma aldea ${ }^{145}$, en lo que podemos entender como una renuncia sobre sus derechos en Villamiel, que ya había sido previamente donada. En febrero de 1176 Alfonso VIII confirmó a la Orden la posesión de Villamiel ${ }^{146}$. Poco más de un año antes, Pedro y Sancho lbáñez habían donado a los freires una heredad de cinco yugadas en esta aldea, con casas, prados y pastos, además de la retención del usufructo vitalicio, a cambio del cual los sanjuanistas recibirían anualmente una fanega de trigo. La donación la recibieron los frejres hospitalarios Rodrigo Pelayo y Gutierre Pérez de Reinoso ${ }^{147}$.

Sin embargo, no eran los hospitalarios los únicos que podían reclamar derechos sobre esta aldea toledana. Por eso en 1203, Juan Alvacil, en representación propia y de los demás herederos de su abuelo, y el alcalde don Illán, acordaron con la Orden del Hospital, en presencia del alcalde don Esteban, aceptar la sentencia judicial sobre los derechos que tenían en Villamiel ${ }^{148}$.

En la propia villa de Toledo, la más importante de toda la frontera castellano-andalusí, tenía la Orden del Hospital varias propiedades, entre las que destacaba la iglesia de Santa Cruz - antigua mezquita musulmana, conocida actualmente como Cristo de la Luz-, donada por Domingo Pérez en $1183^{149}$, y cuyos derechos eclesiásticos fueron acordados tres años más tarde por Alfonso VIII y el arzobispo de Toledo ${ }^{150}$. Siete años

142 A. Gonzalez Palencia, Los mozárabes de Toledo en los siglos xil-xili, 4 vols., Madrid, 1926-1930, vol. preliminar, p. 86. La localización geográfica más precisa en el mapa situado entre las pp. 96 y 97.

${ }_{143}$ Libro de Privilegios, $n .^{\circ} 203$.

144 loid., n. ${ }^{\circ} 101$.

145 lbid., n. 105.

146 lbid, n. ${ }^{\circ} 124$.

147 lbid., n. 116.

148 C. Torroja Menéndez, Catálogo del Archivo del monasterio de San Clemente de Toledo, p. 23.

149 Libro de Privilegios, $n .^{\circ} 145$.

150 Publ. J. GonzÁlez, Alfonso VIII, II, pp. 779-780; P. Guerrero Ventas, El Gran Priorato, pp. 329-330. 
antes Pelayo Pérez donó a los sanjuanistas illas meas casas novas maiores et meliores quas habeo in Toleto, et sunt fabricate super viam publicam que vadit ad ecclesiam maiorem Beate Marie ${ }^{151}$. A las mencionadas se unían otras casas como la conseguida en Zocodover (1184) de la freira hospitalaria doña Misol ${ }^{152}$, la comprada tres años después a María Pascual, in via que ducit ad Alcantaram, o las que probablemente los freires construyeron en Alhizem, en la propia ciudad de Toledo, donde Alfonso VIII donó un solar para tal fin, situado inter ortum meum qui est sub meo alcaçar et hospitale milicie Sancti lacobi et ecclesie Sancte Marie de Alhicem et monasterium Sancti Petri ${ }^{153}$.

Por otra parte, desde finales del siglo Xil la Orden tenía también establecimientos de venta en Toledo, especialmente rentables a partir de 1190 , cuando Alfonso VIII concedió franquicia a las tiendas hospitalarias ${ }^{154}$. Desde comienzos del siglo XIII, se constata la existencia de un mesón sanjuanista en el barrio de Santa María Magdalena, en el arrabal del Rey. Una idea aproximada de su valor puede desprenderse de la venta que se hizo en febrero de 1209 sobre un mesón contiguo por valor de 40 mizcales de oro alfonsies ${ }^{155}$. Ese mismo año la Orden de San Juan compró a Vela García y Urraca Garcíez casas, baños, hornos y huertos con todas sus pertenencias en la villa de Toledo ${ }^{156}$.

Entre las huertas toledanas de los sanjuanistas sobresalía la de Almozavara, en el lugar llamado Azanad, junto a una viña de la Orden de Calatrava ${ }^{157}$ y la almunia regia. Fue donada por el conde don Gonzalo en junio de 1168, acompañada de casas, molinos, tiendas y hornos en Toledo ${ }^{158}$, y confirmada por Alfonso VIII en 1182, cum suis aquis et aqueductilibus, cum arboris fructiferis et non fructiferis et cum omnibus directiuris suis ${ }^{159}$. También en la cuenca del Tajo, entre el castillo de Aceca y la ciudad de Toledo, la Orden recibió del rey siete aran-

151 Libro de Privilegios, n. ${ }^{\circ} 123$

152 En mayo de 1184 esta freira sanjuanista autorizaba a la Orden a desempeñar una casa en Zocodover y una viña en Aceca que había entregado a cambio de 40 y 20 maravedís respectivamente, con la condición de retener el usufructo vitalicio y de que se le concediera algún prestimonio. Publ. Libro de Privilegios, n. ${ }^{\circ} 152$.

153 Ibid., n. ${ }^{\circ} 160$ y 193.

154 Ibid., n. ${ }^{\circ} 173$.

155 A. González Palencia, Los mozárabes de Toledo en los siglos XII-XIII, I, n. ${ }^{\circ} 366$. El mesón de la Orden del Hospital se vuelve a citar varias veces a lo largo del siglo XIll. Vid. Ibid., II, n. ${ }^{\circ} 409$, 413,440 y 474.

156 Libro de Privilegios, n. ${ }^{\circ} 203$

157 J. GonzAlez, Alfonso VIII, II, pp. 201-203.

158 Libro de Privilegios, $n .^{\circ} 101$.

159 lbid., n. ${ }^{\circ} 143$. 
zadas de viña y de María Pascual una heredad, ambos bienes estaban situados en Mazarabuzaque ${ }^{160}$, aldea perteneciente al término de Toledo ${ }^{161}$. Más cerca de la capital del reino, en la propia villa de Aceca, los freires consiguieron una viña en 1184 tras llegar a un acuerdo con doña Misol ${ }^{162}$.

Probablemente, se encontraban también al norte del Tajo las heredades que Rodrigo Rodríguez tenía en San Martín de Avanares de Suso e de luso y en San Pantaleón, entregadas a la Orden de San Juan en el testamento que este personaje realizó entre febrero y marzo de $1189^{163}$.

\subsection{El sector occidental del reino de Toledo}

El sector occidental del reino de Toledo estaba constituido, básicamente, por las tierras de Talavera y Montalbán y los alfoces de los concejos de la cuenca media del Alberche: Santa Olalla, Maqueda y Escalona.

Precisamente en el alfoz de Escalona estaba la heredad que tenía la Orden en la aldea de Cadalso ${ }^{164}$. Anteriormente había pertenecido a Pedro Domínguez, pero en septiembre de 1188 Alfonso VIII la había donado a las sanjuanistas ${ }^{165}$.

Más al sur, la Orden del Hospital tenía algunas heredades en término de Maqueda, villa que desde 1201 pertenecía a la Orden de Calatrava por donación de Alfonso VIII ${ }^{166}$. Casi dos décadas antes, los sanjuanistas ya contaban con propiedades en el alfoz de Maqueda, en concreto con la aldea de la hija de Domingo Esteban, que en 1182 Pedro Porcón y su mujer Senice donaron a la Orden, con la condición de vivir en ella ${ }^{167}$. Más adelante, probablemente en junio de 1212 , el comendador de Olmos compró a María Cristóbal una aldea y heredad en

160 Ibid., n. 157 y 160.

161 Localización en J. GonzALEZ, Repoblación, II, mapa entre las páginas 176 y 177.

162 Libro de Privilegios, $\mathrm{n} .^{\circ} 157$.

163 AHN, Códices, sign. 996B, fols. $75 v-76 v$. Resumen amplio y justificación de la datación en F.J. HeRnández, Los Cartularios de Toledo, $n .{ }^{\circ} 228$.

164 Probablemente se trata de la actual localidad madrileña de Cadalso de los Vidrios, entonces situada en el término de Escalona. Cfr. G. MARTínez DiEZ, «Estructura administrativa local», pp. 101-102.

165 Libro de Privilegios, n. 164.

166 Publ. J. GonzÁlez, Alfonso VIII, III, pp. 246-247.

167 Libro de Privilegios, n. ${ }^{\circ}$ 141. Desconocemos la ubicación exacta de la aldea, pero parece clara su relación con la tierra de Maqueda ya que entre las autoridades de referencia figura, imperante sub eo Maquede, Didacus Simeonis. 
término de Maqueda, cerca de la heredad que ya poseian los freires sanjuanistas, además de unas tierras próximas al molino del herrero por 150 maravedís ${ }^{168}$.

En el extremo occidental de la frontera, la Orden del Hospital adquirió algunas propiedades en el extenso alfoz talaverano ${ }^{169}$, que constituyeron la base para la configuración de la encomienda de Talavera ${ }^{170}$. Así, en octubre de 1182 Pedro Cabañero y su mujer María Meléndez donaron a los sanjuanistas dos tierras y medio prado en la aldea de Borgel, situada en el término de Talavera ${ }^{171}$. Una década después, doña Águeda vendió a la Orden del Hospital la aldea de Pedro Pérez el Tuerto, junto al Alberche, en término de Talavera, por 33 maravedís ${ }^{172}$. Un año después, el comendador Pedro de Lamas compró a Pedro Cañadilla las casas, viñas, tierras, prados y otros bienes que tenía en la aldea de Cañadilla por quince maravedís ${ }^{173}$. Por último, en julio de 1214 , don Juan, prior del monasterio cisterciense de Valdeiglesias, y frey Diego, en representación del abad Ostenz y todo el cenobio, vendieron a frey Martín, comendador hospitalario de Talavera, una huerta en término de la citada villa por 50 maravedís. La huerta limitaba al este con otra huerta que ya tenían allí los freires sanjuanistas ${ }^{174}$.

168 Ibid., n. 209.

169 Sobre las posibilidades de expansión meridional de la tierra de Talavera, motivada por la presión septentrional del concejo de Ávila, vid. J. Gómez-MEnOR, La antigua tierra de Talavera, Toledo, 1965; María Jesús SuÁrez Álvarez, La villa de Talavera y su tierra en la Edad Media (1369-1504), Oviedo, 1982; Fernando JIMÉNEZ de Gregorio, Los pueblos de la provincia de Toledo hasta finalizar el siglo XVIII. IV. Talavera de la Reina, Toledo, 1983; E. Rodriguez-PICAvEA MatILLA, La villa y la tierra de Talavera en la plena Edad Media. Orígenes, consolidación y desarrollo de un concejo de realengo (siglos Xi-xili), Talavera de la Reina, 1996; G. MARTinez DiEZ, «Estructura administrativa local", pp. 107-115.

170 La huella de la Orden en la toponimia talaverana ha quedado reflejada en el barrio de San Juan de la villa.

171 Libro de Privilegios, $n .^{\circ}$ 142. Su localización podria relacionarse con el despoblado de Brujel, en el actual término municipal de Lucillos. Cfr. G. MARTinez DiEZ, "Estructura administrativa", p. 112; J. Gómez-MENor, La antigua tierra de Talavera, pp. 50 y 132; M.J. SuÁrez Álvarez, La villa de Talavera y su tierra en la Edad Media, pp. 80-81.

172 Libro de Privilegios, n. 176.

$173 \mathrm{Jbid}$. n. ${ }^{\circ}$ 177. Es posible que el topónimo se pueda localizar en las inmediaciones del arroyo de las Cañadillas, en el término municipal de Sevilleja de la Jara (M.T.N., Hoja 682; y Diccionario geográfico de España, Madrid, 1961, tomo 6, p. 444), que estaba dentro de los límites del concejo de Talavera, pero en una posición excesivamente meridional y muy despoblada a finales del siglo x ı. Vid. G. MARtinez Diez, «Estructura administrativa local», pp. 107-115. La otra posibilidad es relacionar el topónimo Cañadilla con un despoblado del mismo nombre situado en el término municipal de Lagartera, pero perteneciente ya a los límites del alfoz de Ávila. Cfr. MADOz, Diccionario, voz Cañadillas; y M.T.N., Hoja 600.

${ }^{174}$ Libro de Privilegios, n. 211. 


\subsection{La Mancha}

Desde mediados del siglo XII la Orden del Hospital estaba implicada en la articulación social de La Mancha, la zona más meridional del reino de Toledo ${ }^{175}$. En 1150 tal vez consiguieron de Sancho III la que probablemente es la más avanzada de sus posiciones a lo largo del siglo XII, la aldea de Arenas de San Juan ${ }^{176}$. Muy cerca de allí, Alfonso VIII donó en $1162{ }^{177}$ las villas de Criptana ${ }^{178}$, Ajos ${ }^{179}$, Quero ${ }^{180}$ y Tirez ${ }^{181}$. La Orden

175 Sobre el señorio manchego de la Orden del Hospital ha trabajado en los últimos años J. Molero García, "Sistemas de defensa y control en el Campo de San Juan: del dominio musulmán al cristiano (siglos x-xıII), IV Congreso de Arqueología Medieval Española, II, Alicante, 1993, 399405; “Torres exentas y atalayas medievales en el Campo de San Juan», en Actas del / Congreso de Castellología lbérica, Palencia, 1998, 513-531; "Carácter y función de la fortíficación sanjuanista", en A. Madrid y H. O'Donnell, eds., Actas de las II Jornadas de Historia de la Orden de San Juan (Arenas de San Juan, abril de 1998), Ciudad Real, 1999, 149-168; "Caminos y poblamiento en el Campo de San Juan", en R. Izquierdo y F. Ruiz, eds., Las Órdenes Militares en la Peninsula Ibérica, I. Edad Media, Cuenca, 2000, 111-142; y «Espacios y sociedades: Los primeros tiempos del Hospital en La Mancha (1162-1250)", en R. Izquierdo, F. Ruiz y J. Molero, eds., La Orden Militar de San Juan en la Peninsula lbérica durante la Edad Media. Actas del Congreso Internacional celebrado en Alcázar de San Juan los días 23, 24 y 25 de octubre de 2000, Alcázar de San Juan, 2002, 169-221. Se refieren también a esta zona los trabajos de C. Ayala MartínEZ, "Las Órdenes militares y la ocupación del territorio manchego (siglos X\|-XII", y C. BARQUERO GoÑI, "La Orden Militar del Hospital en la Mancha durante los siglos XII y XIII", ambos publicados en R. Izquierdo y F. Ruiz, eds., Alarcos 1995. Actas del Congreso Internacional conmemorativo del VIII Centenario de la batalla de Alarcos, Cuenca, 1996, 47-104 y 289-313, respectivamente.

176 Fue confirmada posteriormente por Alfonso VIII. Vid. Biblioteca del Palacio Real, Ms. 1531, fol. 121; P. Guerrero Ventas, El Gran Priorato, p. 39.

177 Publ. J. GonzÁlez, Alfonso VIII, II, pp. 97-99.

178 Se localiza en el actual término municipal de Campo de Criptana, en la ermita Virgen de Criptana (M.T.N., Hoja 714), donde estaba el antiguo castillo derribado en época de los Reyes Católicos. Vid. Carmelo Viñas y Ramón PAZ, Relaciones Histórico-Geográficas-Estadisticas de los pueblos de España hechas por iniciativa de Felipe II. Ciudad Real, Madrid, 1971, pp. 166 y 169. Criptana dejó pronto de pertenecer a la Orden del Hospital, en el acuerdo de 1237 con la Orden de Santiago se estableció que los freires del convento de Uclés tuviesen bajo su jurisdicción la villa de Criptana, con todos sus términos. Publ. D.W. Lomax, La Orden de Santiago, Madrid, 1965, pp. $257-$ 262; Aguirre, El Gran Priorato, pp. 65-70; Reg. M. Rivera Garretas, La encomienda, p. 369.

179 Posiblemente el despoblado de Ajos se localiza en las inmediaciones de la actual ermita del Cristo de Villajos, cercana a un poblado ibérico, en el término municipal de Campo de Criptana (M.T.N., Hoja 714). En el siglo XVI la ermita estaba bajo la advocación de la Señora de Villajos. Cfr. VINAS-PAZ, Relaciones, 171. En principio, parece descartable la ubicación de esta villa al sur de la de Criptana (M. Rivera Garfetas, La encomienda, p. 515 y mapa entre las páginas 136 y 137). La toponimia actual y la propia ordenación de las villas en el documento, que sigue un claro criterio geográfico en dirección sur-norte, no avalan la hipótesis de Rivera. En cualquier caso, la presencia sanjuanista en Villajos fue también pasajera, pues en el acuerdo de 1237 con la Orden de Santiago (vid. nota anterior) pasó también a la jurisdicción del convento de Uclés.

180 Es la única de las cuatro villas que ha subsistido hasta la actualidad (M.T.N., Hoja 687).

181 Según AguiRre (El Gran Priorato, p. 161), la villa de Tirez estaba en la segunda mitad del siglo xvill en las Casas y Pozo del Tirez, en término de Consuegra. La localización del despoblado probablemente en las inmediaciones de la laguna de Tirez (M.T.N., Hoja 687), en el actual término municipal de Villacañas. 
cedió enseguida la mitad de todas ellas a Miguel Asarafí ${ }^{182}$, para que colaborase en la colonización del territorio.

Sin embargo, la más importante de todas las posesiones sanjuanistas en la frontera castellano-andalusí fue sin duda el castillo de Consuegra. En 1151 Alfonso VII lo había cedido a Rodrigo Rodríguez, con amplios términos que llegaban hasta el río Riánsares, los límites de Lillo, Bogas y Mora, el camino de Toledo a Calatrava, Puente Seca, Calderina, el canal de Griñón, el río Guadiana y Criptana, hasta llegar de nuevo al Riánsares ${ }^{183}$. En 1173 Rodrigo Rodríguez consiguió canalizar a través de Consuegra el portazgo de las recuas que se dirigiesen a tierra de Segura ${ }^{184}$. Estos términos y derechos debieron pasar a poder de la Orden del Hospital cuando en agosto de 1183 Alfonso VIII le donó el castillo de Consuegra:

Dono itaque vobis et concedo castellum quod dicitur Consogra, in fronteria maurorum prope Toletum situm, totum integre cum ingressibus et egressibus, cum collatiis et solaribus populatis et heremis, cum terris, vineis et ortis, cum pratis, pascuis, rivis, aquis, molendinis, aceniis et eorum locis, et cum omnibus portaticis suis et mineriis que sunt in termino eius et inveniri poterunt, et cum montibus, fontibus, nemoribus et defesis et cum omnibus terminis, directuris et pertinentiis suis, iure hereditario in perpetuum libere et quiete habendum et irrevocabiliter possidendum ${ }^{185}$.

La fortaleza de Consuegra, cabeza de la encomienda del mismo nombre, reforzó su posición en los años de tránsito del siglo XII al XIII. En esas fechas, cuando quedó expuesta en primera línea fronteriza, recibió rentas extraordinarias procedentes de la monarquia - 30 cahíces de medida toledana en las salinas de Belinchón, la promesa de 2.000 maravedís anuales en el testamento del monarca- además de la canalización del portazgo de las recuas que por allí transitasen camino de al-Andalus ${ }^{186}$. Finalmente, la consolidación de la villa consaburense se verificó con la entrega de un documento foral inspirado en el de Cuenca. Es posible que pertenezca también a este período la noticia del establecimiento de dos jueces en Consuegra.

182 AHN, OO.MM., carp. 455, n. 5 .

183 Publ. AguiRre, El Gran Priorato, pp. 50-51; Libro de Privilegios, n. 64 . Según Aguirre, Consuegra fue tomada de nuevo por los musulmanes y reconquistada por Alfonso VIil en 1177. El error proviene de la confusión con el fuero de Cuenca, que efectivamente fue tomada en aquel año.

184 Publ. J. González, Altonso VIII, II, pp. 297-298; P. Guerrero Ventas, El Gran Priorato, p. 334 .

185 Publ. Libro de Privilegios, n. 144.

186 J. GonzÁlez, Alfonso VIII, II, pp. 341-347, 656, 860; Libro de Privilegios, n. 190 y 191. 
La más efímera de las propiedades sanjuanistas en La Mancha fue Uclés, donada conjuntamente por Fernando II y Alfonso VIII en $1163^{187}$, para controlar la frontera musulmana de Cuenca. Al parecer los hospitalarios no cumplieron con las expectativas en ellos depositadas, razón por la cual Uclés fue cedida en 1174 a la Orden de Santiago ${ }^{188}$.

Más adelante, en fecha que no podemos precisar -probablemente ya en el siglo xIII-, la Orden hospitalaria se hizo con el dominio de las avanzadas fortalezas de Peñarroya, Ruidera, Santa María ${ }^{189}$ y Villacentenos ${ }^{190}$, todas ellas situadas en el sector más meridional del señorio sanjuanista en el reino de Toledo ${ }^{191}$. En junio de 1215 Enrique I concedió a la Orden que pudiera acotar dehesas en cada uno de los castillos mencionados, especificando los tributos que debía pagar el ganado que las utilizara ${ }^{192}$. Muy poco después esta zona constituiría una encomienda independiente con cabeza en Peñarroya ${ }^{193}$.

Por último, las más meridionales de cuantas propiedades adquirieron los sanjuanistas en el reino de Toledo durante el período que estamos analizando fueron las casas, viña, huerta, molino y heredad de Cortes, muy cerca de Alcaraz, que por mandato de Alfonso VIII había donado a la Orden el merino regio Pedro Fernández ${ }^{194}$.

\section{LA EXPLOTACIÓN DEL PATRIMONIO SANJUANISTA: LA FISCALIDAD SEÑORIAL}

La explotación del dominio señorial de la Orden del Hospital persigue la obtención de un beneficio mediante la apropiación de los exce-

\footnotetext{
187 Libro de Privilegios, n. $^{\circ} 91$.

188 Publ., entre otros, J.L. Martín Rodriguez, Origenes de la Orden Militar de Santiago, pp. 240-241.

189 Puede comprobarse la localización de estas tres fortalezas en el sector suroriental del término municipal de Argamasilla de Alba. Vid. Mapa Provincial de Ciudad Real, Escala 1:200.000, Instituto Geográfico Nacional. La localización de la antigua fortaleza de Santa Maria se relaciona con unas ruinas que reciben el nombre de Vega de Santa María.

190 Es posible relacionarlo con el despoblado que, según MAdoz (Diccionario, voz Villacentenos) está situado en el término municipal de Alcázar de San Juan, a tres leguas de esta villa, sobre el camino que conduce a Manzanares.

191 Un estudio de estas cuatro fortalezas en J. MOLERo García, «Fortificaciones sanjuanistas en La Mancha: los cuatro castillos de la ribera del Guadiana", Castillos de España, 115 (1999). 3-18.

192 Libro de Privilegios, n. 215.

193 Ibid., n. ${ }^{\circ} 218$.

194 Ibid., n. ${ }^{\circ} 210$.
} 
dentes. Éstos pueden obtenerse a través de una explotación estrictamente económica -en casos excepcionales-, o, sobre todo, a través de la explotación jurisdiccional. En este sentido, se puede entender la fiscalidad señorial como el producto de la materialización económica de las relaciones sociales y de producción en el marco del señorío. En definitiva, la renta feudal es el conjunto de ingresos y derechos señoriales procedentes de la explotación económica y jurisdiccional del dominio señorial. Entre las rentas derivadas de la explotación jurisdiccional se pueden distinguir tres niveles: el típicamente señorial, el propiamente jurisdiccional y el eclesiástico ${ }^{195}$.

\subsection{Rentas típicamente señoriales}

Son aquellas que proceden del reconocimiento del señorío por parte de los habitantes que integran el dominio. Tal reconocimiento del señorío convierte a los habitantes del mismo en vasallos del señor. No extraña, por tanto, el hecho de que se trate de unas rentas derivadas de algunas de las

195 Por lo que se refiere a la extensa bibliografia sobre la cuestión de la renta feudal citaremos solamente los trabajos más significativos de las dos últimas décadas, ya que en todos ellos se pueden encontrar numerosas referencias a lo realizado anteriormente. Especial interés por el estudio de esta cuestión ha mostrado Julián CLEMENTE Ramos en varios de sus estudios, de los que destacamos por su carácter globalizador: «Buenos y malos fueros. Aportación al estudio de la renta feudal en Castilla (ss. XI al XIII)", Norba. Revista de Historia, 5 (1984), 117-126; "La renta feudal en Castilla y León a través de algunos de sus ejemplos", Norba. Revista de Historia, 6 (1985), 99-112; y Estructuras señoriales castellano-leonesas. El realengo, Universidad de Extremadura, 1989, pp. 173-233. Junto a esto, resulta imprescindible la consulta de las aportaciones de P. Martinez Sopena, La Tierra de Campos Occidental, Valladolid, 1985, pp. 249-320; C. ESTEPA DiEZ, “Formación y consolidación del feudalismo en Castilla y León”, En torno al feudalismo. I Congreso de Estudios Medievales, Fundación Sánchez Albornoz, Ávila (1989), 157-256; M.A. Ladero Quesada, Fiscalidad y poder real en Castilla (1252-1369), Madrid, 1993; y C. AyalA MARTINEZ, “Relaciones de propiedad y estructura económica del reino de León: los marcos de producción agraria y el trabajo campesino (850-1230)". El Reino de León en la alta Edad Media, VI, León, 1994, 133-408. En cuanto a la problemática concreta de las Órdenes militares en relación con la renta feudal citaremos también los estudios más recientes: M. Rodriguez LLOPIS, Señorios y feudalismo en el reino de Murcia, Murcia, s.a., pp. 275-317; C. LALIENA, Sisterma social, estructura agraria y organización del poder en el Bajo Aragón en la Edad Media (siglos XII-XV), Teruel, 1987, pp. 127-152 y 263-276; R.G. PEINAdo SANTAELLA, «La renta señorial en las Órdenes militares de la Corona de Castilla durante la Baja Edad Media", Historia. Instituciones. Documentos, 18 (1991), 403-424; E. RODRIGUEZ-PICAVEA, La formación del feudalismo en la meseta meridional castellana. Los señorios de la Orden de Calatrava en los siglos XII-xM, Madrid, 1994, pp. 335-374; P.A. Porras Arboledas, La Orden de Santiago en el siglo xv. La Provincia de Castilla. Madrid, 1997, pp. 173-225; C. BARQUERO GOÑI, "Los hospitalarios en el reino de León (siglos xII y XIII)" en El reino de León en la Alta Edad Media IX, León, 1997, 219-634, pp. 423-439; J.V. Matellanes Merchán, Organización social y económica de la Orden de Santiago en la Transierra casteliano-leonesa. Sigios XI-xII, Universidad Autónoma de Madrid, 1998; y F. NovoA PORTELA, La Orden de Alcántara y Extremadura (siglos XII-XIV), Mérida, 2000, pp. 233-276. 
antiguas fórmulas de encomendación campesina y asociables al concepto de "vasallaje rural". Frecuentemente se materializan a través de contratos agrarios colectivos de finalidad pobladora.

Indiscutiblemente estamos ante el tipo de ingresos que esencialmente sustentan la estructura socio-productiva del sistema feudal. Unas rentas señoriales que se fundamentan en vínculos de dependencia personal entre los propietarios eminentes del suelo y los usufructuarios del mismo, que deben pagar a los primeros una serie de prestaciones económicas y laborales en reconocimiento de señorío sobre la tenencia de la tierra. Se trata en definitiva del componente esencial del vasallaje campesino.

\subsubsection{Rentas por unidad de producción u hogar en reconocimiento de señorío}

Entre las rentas tipicamente señoriales se sitúan, en primer lugar, aquellas pagadas por unidad de producción u hogar -tipo infurción, fumazgo, etc...- en reconocimiento del señorio. Así, en Alhóndiga los pobladores pagaban a la Orden del Hospital una renta en reconocimiento de su jurisdicción señorial sobre la heredad que usufructuaban. Incluso, en el caso de que fueran a poblar a otro lugar, debían mantener en explotación su heredad para pagar la renta señorial correspondiente a la Orden ${ }^{196}$.

Por su parte, en Villamiel de Toledo, en los inicios del señorío hospitalario, sus pobladores pagaban a la Orden un tributo anual de dos cahíces $^{197}$. En mayo de 1187 esta renta fue reducida por el comendador de Consuegra a dieciocho fanegas, nueve de trigo y otras tantas de cebada ${ }^{198}$. Más al norte, en la villa de Humanes, sus pobladores se rigieron por los censos impuestos por su anterior señor Pelayo Pérez de Frómista en $1173^{199}$. En esa ocasión se realizó una clara división entre los pobladores que araban las tierras -que debian entregar anualmente a su señor un cahíz- y los que no las araban -que tenían que tributar cuatro fanegas-. En ambos casos la entrega debía realizarse en proporciones iguales de trigo y cebada. No parece que estas condiciones se modificaran

196 E. Hinojosa, Documentos, p. 76. No se especifica la cantidad que deben pagar los pobladores en reconocimiento del señorío sobre sus heredades.

197 Un cahíz equivale a doce fanegas que, por la zona, eran de medida toledana. Cada fanega tenia capacidad para 44 litros. Vid. M.A. LADERO, La Hacienda real de Castilla en el siglo xv, Universidad de La Laguna, 1973, p. 15.

198 Libro de Privilegios, n. ${ }^{\circ} 158$.

199 Ibid., n. 110. 
cuando, a principios del siglo XIII, el prior sanjuanista Gutierre Armíldez entregó fuero a la villa ${ }^{200}$.

Al pago de la infurción individual en algunos lugares se superpuso el yantar como tributo colectivo. Se trata de un derecho que en origen obligaba al vasallo a proporcionar alimentación a su señor, pero que andando el tiempo pasaría a convertirse en no pocas ocasiones en un impuesto pagado en moneda y de responsabilidad comunitaria. Esto es lo que pudo ocurrir en la aldea alcarreña de Peñalver, ya que en el fuero se establecía que sus vecinos debian pagar cada año cuatro maravedís a su comendador en concepto de yantar, aunque no se especificaba con claridad que la responsabilidad del tributo fuera individual o colectiva ${ }^{201}$.

\subsubsection{Monopolios señoriales}

El otro capítulo importante de las rentas típicamente señoriales lo constituían los monopolios de la Orden. En líneas generales, podemos reseñar que los molinos hidráulicos no constituían para los hospitalarios un monopolio jurídicamente sancionado, debido al elevado coste que tenian estas infraestructuras. Solamente contamos con una excepción referida a la aldea toledana de Villamiel. Allí, en febrero de 1185, el prior Pedro Arias otorgó potestad a sus pobladores para que construyesen un molino, con la condición de que la mitad de todas sus rentas fuera para los freires sanjuanistas ${ }^{202}$. En este caso, resulta indiscutible que la Orden tenia potestad para conceder la licencia de construcción de molinos en virtud de su señorío sobre Villamiel. Se trata, en consecuencia, de un derecho típicamente señorial, que genera además la percepción de una renta para el Hospital.

Por el contrario, los hornos parecen constituir en la práctica totalidad de los dominios sanjuanistas de la región un monopolio señorial, sancionado además por algunos fueros bajo la simbólica expresión de forno de palacio, a la que se añadía la no menos significativa e otro non sea fecho en toda la villa, que recogía el fuero de Peñalver ${ }^{203}$. Tanto en Alhóndiga como en Peñalver el horno tenía capacidad para 30 panes y el responsable de mantenerlo en buen estado era el hornero. Solamente en el caso de producirse una avería en el horno señorial se permitía, hasta su reparación, la

\footnotetext{
200 Ibid., n. 200.

201 bid., n. 77.

202 lbid., n. 155

$203 \mathrm{lbid}, \mathrm{n}{ }^{\circ} 77$.
} 
utilización de otros hornos ${ }^{204}$. Sin embargo, la pena impuesta para todo aquel que llevase a cocer su pan a otro lugar ascendía a diez maravedís ${ }^{205}$, suma notable para un campesino del siglo XII. En la misma línea, el fuero de Humanes de principios del siglo xIII regulaba el monopolio del horno por parte de los sanjuanistas, que ni siquiera serían responsables del daño causado a los panes de los vecinos, quienes debían llevarlos a cocer al horno señorial el jueves ${ }^{206}$.

La relación de monopolios señoriales se completa con el control absoluto sobre la venta del vino, los pesos de la carnicería y las medidas del pan que la Orden del Hospital disfrutó en la aldea de Peñalver. La venta del vino debía realizarse en los meses de abril o mayo y se establecía además que toda aquella persona que vendiera vino en Peñalver y su término sin autorización de la Orden tendría que pagar cinco maravedís. Por su parte, los pesos de la carnicería generaban derechos a favor de los sanjuanistas cada vez que se mataba una res. Lo mismo sucedía con las medidas siempre que fueran utilizadas para calibrar el pan ${ }^{207}$.

\subsection{Rentas propiamente jurisdiccionales}

Se trata de aquellas rentas derivadas de la apropiación señorial o la cesión regia de tributos y derechos teóricamente reales ${ }^{208}$. Es evidente que su desarrollo está relacionado con la organización política, jurídica y social del espacio. Entre las rentas típicamente señoriales existen también connotaciones jurisdiccionales, pero derivadas de relaciones de dependencia personal. Las rentas y derechos que integran el nivel propiamente jurisdiccional, por el contrario, corresponden teóricamente a la autoridad pública, pero como consecuencia de la inmunidad feudal dejan de estar vigentes en las jurisdicciones señoriales o son cedidas a quienes las ejercen. Una subdivisión más pormenorizada permite distinguir dos tipos de rentas 0 derechos dentro de este nivel jurisdiccional: rentas de alcance principalmente económico y derechos que poseen además una clara dimensión gubernativa.

204 E. HinOJOSA, Documentos, p. 74.

205 Libro de Privilegios, $n .77$.

206 Ibia., n. 200.

207 Ibid., n. 77.

208 Por lo que se refiere a las rentas que integran el nivel jurisdiccional resulta fundamental la consulta del completo trabajo del profesor LADERO, Fiscalidad y poder real, ya citado anteriormente. 


\subsubsection{Rentas de alcance principalmente económico}

Entre ellas ocupaban un lugar destacado los impuestos territoriales, reflejo de la antigua fiscalidad pública. En este sentido se puede considerar la obligación que tenía cada vecino de entregar anualmente a la Orden del Hospital un mencal ${ }^{209}$ por la festividad de San Miguel en las aldeas alcarreñas de Peñalver y Alhóndiga ${ }^{210}$. En Peñalver el fuero especificaba expresamente que este pago se realizaba en concepto de pecho.

Al mismo tiempo, la Orden de San Juan tenía potestad para eximir del pago de pecho, lo que indica también que tenía derecho a percibirlo. Normalmente estas exenciones tenían un carácter temporal y el objetivo de incentivar la colonización de una comarca determinada. En el señorío hospitalario de La Alcarria - tanto en Alhóndiga como en Peñalver ${ }^{211}$ todos aquellos que acudieran a poblar eran eximidos durante una año del pago de pecho a la Orden y al concejo. Pero también podía tratarse de exenciones sin limitación temporal, aunque únicamente referidas a determinados individuos. Este es el caso de la disposición que la Orden incluyó en el fuero de Alhóndiga a través de la cual eximía de pecho a todo aquel que fuera hortelano, molinero o yuguero.

Otro tipo de impuestos de alcance principalmente económico eran los de carácter indirecto. Es el caso del portazgo que la Orden recibía en Consuegra sobre todas las recuas que fuesen a tierra de Segura primero y a todo al-Andalus después. Esta circunstancia demuestra la importancia comercial del enclave consaburense, punto básico, junto a Calatrava, de canalización del tránsito mercantil que, pasando por La Mancha, se dirigía a territorio musulmán ${ }^{212}$. La Orden del Hospital contaba también con la potestad de eximir del pago de portazgo a los pobladores de algunos de sus señoríos, señal inequívoca de que tenía la posibilidad de percibirlo. Así lo hizo con los habitantes de la aldea de Peñalver: es franqueada Peñalver sin portago ninguno ${ }^{213}$.

209 El mencal, del árabe mitqâl, equivale según F. MATEU y LLOPIS (Glosario Hispánico de Numismática, Madrid, 1946, p. 129) a sueldo y medio, aunque para M. RuedA (Primeras acuñaciones de Castilla y León, Salamanca, 1991, pp. 46-47) la equivalencia se situaría entre dos y cuatro sueldos, ya que en el siglo xII en el maravedí cabrian entre cuatro y ocho sueldos y el mencal equivaldría a medio maravedí.

210 E. Hinojosa, Documentos, p. 74; Libro de Privilegios, n. ${ }^{\circ} 77$.

211 Ibid.; E. Hinojosa, Documentos, p. 75.

212 Para un panorama general de esta renta jurisdiccional sobre el tránsito de las mercancias vid. el estudio de César Gonzalez Minguez, El Portazgo en la Edad Media. Aproximación a su es. tudio en la Corona de Castilla, Universidad del Pais Vasco, 1989.

213 Libro de Privilegios, n. 77. 
Por lo que se refiere a los derechos militares, en el fuero de Alhóndiga se establece que incluso el juez y los alcaldes, que gozaban de otros privilegios, debian pagar la fonsadera al rey ${ }^{214}$, pero desconocemos si la Orden recibió este derecho en éste u otros lugares.

Para finalizar, se incluyen en este apartado los monopolios de teórica jurisdicción real o las rentas extraordinarias. Uno de esos monopolios regios más destacados fueron las salinas. En 1184 Alfonso VIII donó a la Orden del Hospital las salinas de Beteta, junto con otros bienes y heredades $^{215}$. El mismo monarca entregó en 1200 una renta anual de 30 cahíces de medida toledana en las salinas de Belinchón para el castillo de Consuegra ${ }^{216}$. También para el mantenimiento de esta importante fortaleza sanjuanista el rey castellano dejó en su testamento una renta extraordinaria de 2.000 maravedís durante diez años ${ }^{217}$.

\subsubsection{Rentas o derechos que poseen además} una clara dimensión gubernativa

Se trata de un tipo de rentas o derechos propiamente jurisdiccionales, que sin olvidar el interés económico que tienen, alcanzan además facetas netamente gubernamentales, procedentes de la cesión monárquica de las mismas o de la simple apropiación por parte de los señores. Incluso algunos de estos derechos, como la potestad legislativa, los derechos militares y el control sobre cargos concejiles, no tienen una conversión material en renta, o al menos no tenemos datos que confirmen esa materialización para nuestro ámbito geográfico y marco cronológico. No obstante, nos ha parecido oportuno incluirlos en este apartado para completar de manera más coherente la división conceptual de la renta sanjuanista.

Las noticias más numerosas sobre este tipo de rentas son las procedentes de derechos judiciales -caloñas o multas-. En el fuero de Alhóndiga se regula el pago de un buen número de caloñas cuya cuantía varía según las infracciones, pudiendo alcanzar hasta trece maravedís, cantidad relativamente importante para este tipo de ingresos. En algunas ocasiones se establece el pago de estas multas según el fuero de Huete ${ }^{218}$, pero la versión latina de este ordenamiento foral no ha llegado

\footnotetext{
214 E. Hinojosa, Documentos, p. 76.

215 Libro de Privilegios, n. 154.

216 J. GonzÁlez, Alfonso VIII, III, pp. 656 y 860.

Ibid., III, pp. 341-347.

${ }_{218}$ E. HINOJOSA, Documentos, pp. 74-77
} 
hasta nosotros ${ }^{219}$. En cualquier caso, todas las caloñas se dividian en tres partes: una para los que habían sido perjudicados, otra para la Orden del Hospital y la tercera para el juez, los alcaldes y el concejo ${ }^{220}$. En Peñalver las caloñas podían llegar hasta diez maravedís ${ }^{221} \mathrm{y}$, en ocasiones, aparecían reguladas según el fuero de Guadalajara ${ }^{222}$.

Otros derechos de clara dimensión gubernativa eran los derivados del control sobre cargos concejiles. En Alhóndiga el nombramiento anual de un juez y dos alcaldes - que se realizaba el día de Navidad-correspondía a la Orden y al concejo: iudex et alcaldes duos intret pro manu senioris et concilii. Unoquoque anno mutetur iudicem et alcaldes in die Natalis ${ }^{223}$.

Por su parte, los derechos legislativos y la potestad foral que ostentaban los sanjuanistas se demostraron a mediados del siglo XII, cuando los freires concedieron fuero a su aldea de Peñalver ${ }^{224}$. Poco después, en abril de 1170, el prior Juan concedió fuero a Alhóndiga, con la aprobación del prior mayor de la Orden don Pedro Arias ${ }^{225}$. A principios del siglo XIII, el prior de la Orden de San Juan en Castilla Gutierre Armíldez concedió fuero a los habitantes de Humanes ${ }^{226}$. Es cierto, sin embargo, que en la concesión del fuero a Consuegra, el más importante señorío sanjuanista en el reino de Toledo, la iniciativa correspondió probablemente a Alfonso VIII. Sin embargo, la potestad foral de los sanjuanistas conoció mayor desarrollo a lo largo del siglo XIII, cuando la Orden de San Juan extendió el fuero de Consuegra mediante cartas de población entregadas a las villas y aldeas manchegas integradas en su señorío ${ }^{227}$.

La nómina de derechos con dimensión gubernativa se completa con la potestad para convocar expediciones militares. Dada la naturaleza militar de la Orden del Hospital, es muy probable que disfrutara de este derecho, en teoría privativo de la realeza. El fuero de Peñalver contempla la

219 Barrero-Alonso, Textos de Derecho local, p. 262. Se conserva un fuero romanceado del siglo XIII, perteneciente a la familia de los fueros de Cuenca.

220 E. Hinojosa, Documentos, p. 75

221 Libro de Privilegios, $\mathrm{n} .^{\circ} 77$.

222 Se refiere al fuero breve otorgado por Alfonso VII el 3 de mayo de 1133. Publ., entre otros, T. MuÑoz y Romero, Colección de fueros municipales y cartas pueblas, Madrid, 1847, pp. 507-511.

223 E. HiNoJOSA, Documentos, p. 75.

224 Libro de Privilegios, $n .^{\circ} 77$.

225 E. Hinojosa, Documentos, pp. 74-77.

226 Libro de Privilegios, n." 200.

227 D. AguirRe, El Gran Priorato, pp. 96-139; J. Molero Garcia, «Espacios y sociedades: Los primeros tiempos del Hospital en La Mancha (1162-1250)", pp. 197-200. 
posibilidad de que cualquier vecino que, por voluntad propia, quisiera acudir al fonsado con el señorío y en la tierra tuviera libertad para hacerlo, aunque sólo estaba obligado a acudir al fonsado por mandato del rey ${ }^{228}$. Esta misma obligación se estableció en el fuero de Alhóndiga: nullus vicinus Hospitalis eat in fonsado nisi per mandato regis ${ }^{229}$.

\subsection{Rentas eclesiásticas}

La Orden del Hospital recibió rentas o derechos de carácter eclesiástico en las villas y aldeas de su señorío. Durante el siglo XII, en los señoríos sanjuanistas la percepción de este tipo de derechos no parece que planteara excesivos problemas. En Alhóndiga, por ejemplo, cada vecino debía entregar a la Orden del Hospital diezmos y primicias ${ }^{230}$. Por los datos posteriores los sanjuanistas también debieron percibir derechos eclesiásticos en Consuegra y su término.

Por el contrario, en aquellos lugares donde la Orden no ostentaba el señorío surgieron los conflictos. Así, ocurrió con la Iglesia de Toledo. Por eso el papa Alejandro III exhortó a los hospitalarios de la provincia de Toledo a respetar los derechos eclesiásticos del arzobispo y obispos sufragáneos en sus respectivas diócesis ${ }^{231}$. Fundamentalmente insistía en que no retuvieran los diezmos de los colonos de las villas que correspondían a las autoridades eclesiásticas del lugar. En junio de 1186 se presentó un problema más concreto con la iglesia de Santa Cruz, próxima a la puerta de Valmerdón, en Toledo, que los freires sanjuanistas habían adquirido en 1183 por donación de Domingo Pérez. El arzobispo de Toledo había consentido el establecimiento de la iglesia hospitalaria, pero bajo condiciones que no perjudicasen sus intereses: no recibir parroquianos y no percibir diezmos, primicias o cualquier otro derecho eclesiástico. Los hospitalarios no respetaban estas prohibiciones, por lo que Alfonso VIII y el arzobispo don Gonzalo llegaron a un acuerdo para que la Orden cumpliese con las citadas prescripciones, ya que en caso contrario la iglesia pasaría a la potestad y jurisdicción del arzobispo, sin que los freires pudieran conservar nada en ella ${ }^{232}$.

228 Libro de Privilegios, $\mathrm{n} .^{\circ} 77$.

229 E. Hinojosa, Documentos, p. 76.

230 Ibid., p. 74

231 Publ. J. Delaville, Cartulaire, I, pp. 334-335; P. Guerrero Ventas, El Gran Priorato, pp. 330-331. Está fechado el 10 de octubre en Ferentino, pero no figura el año. Delaville lo data en 1175, mientras Guerrero lo fecha en 1170.

232 Publ. J. Gonzalez, Alfonso VIII, II, pp. 779-780; P. Guerrero Ventas, El Gran Priorato, pp. 329-330. 
En cualquier caso, los problemas por la percepción de diezmos y derechos entre los sanjuanistas y los arzobispos de Toledo continuaron. Por eso en abril de 1213 el papa Inocencio III, atendiendo a las quejas del arzobispo de Toledo Rodrigo Jiménez de Rada sobre que los freires de la Orden del Hospital y otros religiosos intentaban sustraer los derechos correspondientes al arzobispo en los lugares dependientes de su metrópoli desde antiguo, encomendó al obispo, al arcediano y al tesorero de Osma que juzgaran esta causa. En diciembre del mismo año el pontífice romano encargó al deán de Segovia y a los abades de Valbuena y La Vid que juzgaran la querella interpuesta por el arzobispo de Toledo contra los freires sanjuanistas de las diócesis de Toledo y Cuenca en relación a los daños sobre los diezmos, iglesias, villas, posesiones y otros bienes ${ }^{233}$.

Algo similar ocurrió con el oratorio que tenía la Orden de San Juan en Atienza, pues el obispo de Sigüenza negaba el derecho de los hospitalarios a poseerlo, al no haber en la citada villa un convento de la Orden. Finalmente, en febrero de 1200 los sanjuanistas realizaron una concordia con el obispo don Rodrigo, según la cual no debian recibir en el oratorio a ninguna persona de la diócesis de Sigüenza. No obstante, en Atienza los freires consiguieron autorización para percibir derechos de sepultura por parte de los peregrinos que allí quisieran ser enterrados ${ }^{234}$. A pesar de todo, el obispo no parecía muy dispuesto a facilitar la presencia hospitalaria en Atienza, ya que el papa Inocencio III tuvo que ordenarle, en mayo de ese mismo año, que consagrara el oratorio de la Orden de San Juan ${ }^{235}$.

233 Publ. C. BARquero Goñl, Los hospitalarios en Castilla y León (siglos XII y XIII), doc. 278 y 280. Un estudio más amplio sobre las relaciones entre los sanjuanistas y los arzobispos de Toledo en C. Barquero Goñl, "Los hospitalarios y el arzobispado de Toledo en los siglos $x \|$ y $x \| I !$ ", Hispania Sacra, 45 (1993), 171-183.

234 Publ. T. Minguella y Arnedo, Historia de la diócesis de Sigüenza, I, pp. 507-508. Lo fecha el 8 de marzo de 1200 en Sigüenza, pero en el documento está datado en las 8 kalendas de marzo, que es el 22 de febrero de 1200.

235 Publ. T. Minguella, Historia de la diócesis, I, p. 508; D. Mansilla, Inocencio III, p. 260. 


\section{APÉNDICE I \\ COMENDADORES HOSPITALARIOS \\ EN EL REINO DE TOLEDO (1185-1216)}

1. COMENDADORES DE TRANSIERRA-CONSUEGRA

Fernando Díaz (febrero de 1185)

Rodrigo Rodríguez (junio de 1185)

Melendo Díaz (1187)

Sancho (1198)

Gonzalo Rodríguez (h. 1209)

Montesino (h. 1208-1210)

Roy Muñoz (1212?)

Gutierre Armíllez (mayo y noviembre de 1216)

2. COMENDADORES DE VILLAMIEL

García (1185)

Pedro Aimar (1187)

3. COMENDADORES DE TOLEDO

Garcia (1187)

Martín Vicente (1216)

4. COMENDADORES DE TAJUÑA

Arnaldo (1187)

5. COMENDADORES DE TALAVERA

Pedro de Lamas $(1192,1193)$

Martín $(1214,1216)$

6. COMENDADORES DE HUMANES

Rodrigo Morici (1209) 
7. COMENDADORES DE MOLINA

Dilecto de Pedro II de Aragón (1211)

8. COMENDADORES DE OLMOS

Pedro Ballestero (1212?)

Juan Ballestero (mayo y noviembre de 1216)

9. COMENDADORES DE CEDILLO

Pedro Martín de Salas (1216)

10. COMENDADORES DE PEÑARROYA

Montesino (1216)

\section{APÉNDICE II \\ EVOLUCIÓN DE LA CREACIÓN DE ENCOMIENDAS HOSPITALARIAS EN EL REINO DE TOLEDO (1185-1216)}

1. Transierra-Consuegra (1185)

2. Villamiel (1185)

3. Toledo (1187)

4. Tajuña (1187)

5. Talavera (1192)

6. Humanes (1209)

7. Molina (1211)

8. Olmos (1212?)

9. Cedillo (1216)

10. Peñarroya (1216) 